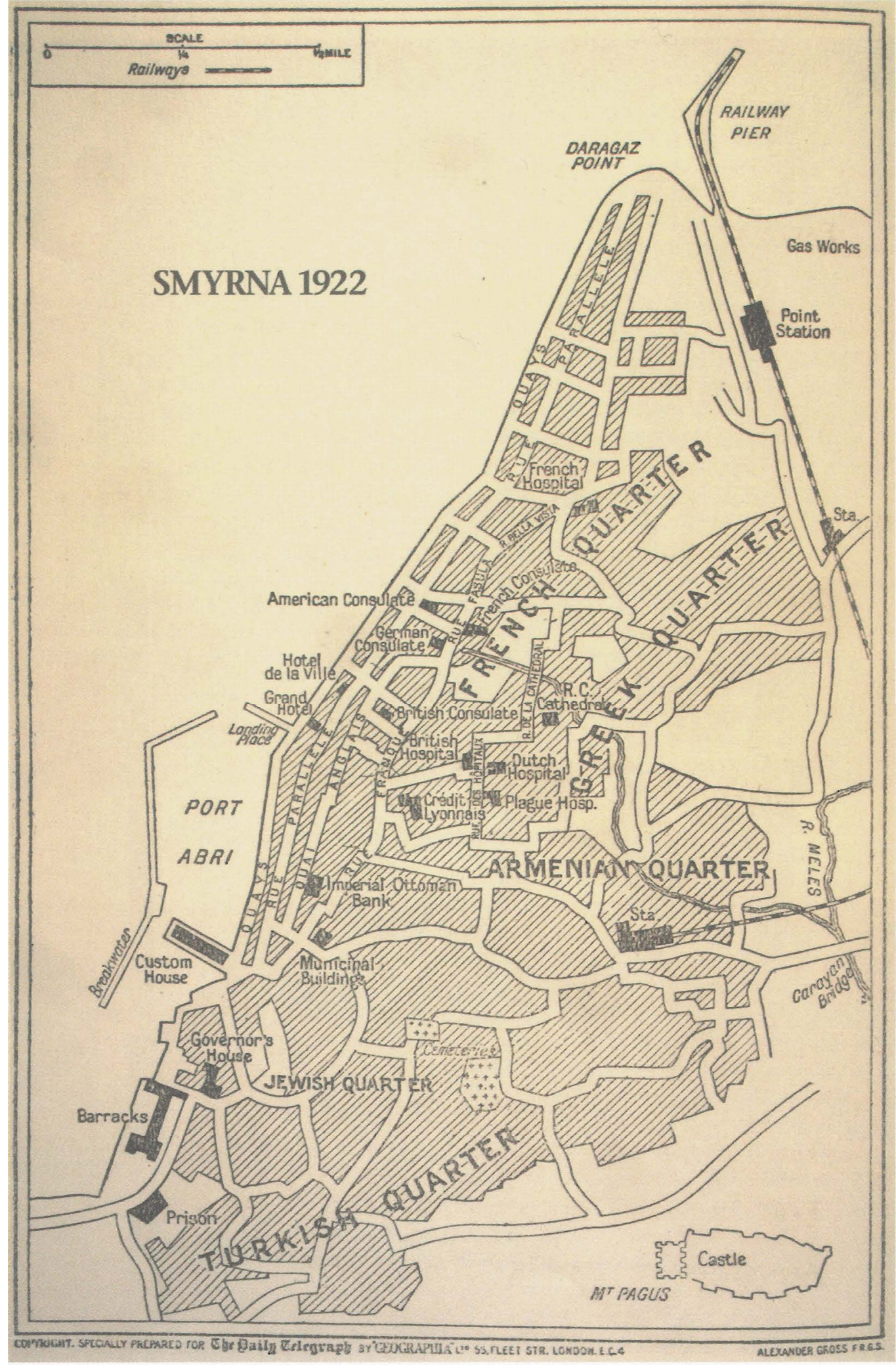

Figure 1. As in the Daily Telegraph, September 6, 1922 


\section{PARADISE LOST: THE MERCHANT PRINCES AND THE DESTRUCTION OF SMYRNA, 1922}

\section{By A.J. Hobbins}

Throughout the Nineteenth Century European merchants built trading empires under the Ottoman Turks in Western Anatolia. Even the least of these merchants could afford a lifestyle that included servants and a house in the better suburbs of Smyma (Izmir). This idyllic existence came to an end after the First World War following the collapse of the Ottoman Empire, an annexation of Anatolia by Greek forces and, ultimately, the military triumph of the resurgent Turkish nationalist forces led by Mustafa Kemal. These actions resulted in the burning of Smyrna in 1922 and a dramatic change in the lives of all inhabitants, including the foreign merchants. This article presents some views of the European colony in Bournabat (Bornova), a Smyrna suburb, of the events of 1922, based on principally on unpublished letters, diaries and other documents.

Sous le l'empire Ottoman, des marchands européens ont bâti au cours du XIXe siècle des empires commerciaux en Anatolie occidentale. Le plus petit de ces marchands pouvait alors s'offrir une maison avec domestiques dans les plus beaux quartiers de Smyrne (Izmir). Cette existence idyllique a brusquement pris fin en 1922 avec l'incendie de Smyrne, dans la foulée de la Première Guerre mondiale, de la chute de l'empire Ottoman, de l'annexion de l'Anatolie par les Grecs qui a été suivie de la recrudescence des forces nationalistes turques sous Moustapha Kemal. Cet article présente différentes analyses sur cette colonie européenne de Bournabat (Bornova), banlieue de Smyrne, des événements tragiques de 1922, tirées de documents inédits comme des lettres, des mémoires et autre documents d'archives.

$\mathrm{F}$ or three millennia Smyrna, the Ornament of Asia, was one of the great cities of the Mediterranean world. ${ }^{1}$ Located on the Turkish coast of the Aegean Sea and boasting one of the world's great harbours, she prospered despite war, conquest and natural disaster. Under Aeolian, Ionian, Roman, and Byzantine rule, Smyrna grew as a commercial centre until conquest came from the east. The city was sacked by the Seljuk Turks in 1084 , by the Crusaders in 1344, by Tamerlaine in 1402, before becoming part of the Ottoman Empire in 1422. Despite these military disasters and severe damage from earthquakes in 1688 and 1778, Smyrna was rebuilt and grew richer and more popu-

\footnotetext{
1 The primary materiais used in this article, originals and/or transcriptions, will be donated to McGill University Libraries when the article is published. A number of sources have been consulted for background on the rise of modern Turkey and the Greco-Turkish War: in particular Michael Llewellyn Smith, Ionian Visions: Greece in Asia Minor, 1919-1922 (Ann Arbor: University of Michigan Press, 1998), Patrick Balfour (Baron Kinross), Ataturk: a Biography of Mustafa Kemal, Father of Modern Turkey (N.Y.: Morrow, 1965), Harry Howard, The Partition of Turkey: a Diplomatic History, 1913-1923 (N.Y.: Fertig, 1966), Briton Busch, Mudros to Lausanne: Britain's Frontier in West Asia, 1918-1923 (Albany: State University of New York Press, 1976) and Arnold Toynbee and Kenneth Kirkwood, Turkey (N.Y.: Scribner, 1927) have been generally useful. Marjorie Housepian, The Smyrna Affair (N.Y.: Harcourt, Brace, Jovanovich, 1971 ) is a definitive and well-documented work on the destruction of Smyrna.
} 
lous. By the end of the nineteenth century the cosmopolitan city was home not only to Turks and a sizable Jewish ${ }^{2}$ community, but also a majority Christian population of Greeks, ${ }^{3}$ Armenians and other Europeans who worked together in relative amity and in contrast to much of the rest of the Ottoman Empire. The large Greek, Armenian and "Frankish" quarters gave the name Giaour Izmir, infidel Smyrna, to the city. The fashionable suburbs of Bournabat and Boudja ${ }^{4}$ were also home to rich Western European merchants, who exported silks, dyes, spices and tobacco to their homelands. Exports from Smyrna surpassed those of all other Near Eastern seaports, including Constantinople, until 1914. During the First World War in 1915, the Armenian population of Smyrna escaped the mass deportations that led to the genocide of their people in other areas of the Ottoman Empire. This was due in general to Smyrna's multicultural uniqueness and its closeness to the West, and, in particular, to the attitude of the local German army commander, Liman von Sanders (1855-1929), who threatened to use his troops to protect the Armenians if the Turkish authorities attempted to molest them. Smyrna emerged from the war as strong as ever, still one of the most desirable residences in the world. Yet the curious would search in vain for Smyrna on modern maps for in 1922 she, who had survived so much and for so long, ceased to exist.

\section{THE GRECO-TURKISH WAR, 1919-1922}

In 1918 the First World War ended for most of the central powers, but not for Turkey. The Allies began to make claims on the territory of the Ottoman
Empire without waiting for a peace treaty. Enver Pasha, Turkey's wartime leader, had fled to Germany leaving the weak Sultan Mehmed VI (Vahid-ed-Din) as nominal head of state, while Mustafa Kemal (later Kemal Atatürk), Turkey's most successful military commander, was in enforced retirement. In 1919, to Kemal's disgust, he had witnessed French general Louis Franchet d'Espèrey riding into Constantinople at the head of his troops on a white horse, as Mehmed the Conqueror was reputed to have done in 1453. While the allies discussed plans for an independent Armenian state in eastern Anatolia, the French advanced into Cilicia, and both Italy and Greece made claims on southwestern Anatolia. There was general approval in the West for the action of the Allies. Turkey was held in low esteem not only because of recent atrocities and the German alliance, but also because such action represented a continuation of a conflict that predated the Crusades. The occupation of Ottoman territory was largely symbolic for most countries, representing a negotiating point in the future settlement. Other than the British concern for keeping the Dardanelles open, the Allies were interested in gaining economic concessions especially in the petroleum industry. Greece, however, was intent on the permanent occupation of Smyrna and western Anatolia. The Greek army landed at Smyma, the presumed birthplace of Homer, on May 15, 1919 and quickly marched into the interior of Anatolia as far as the Allied Supreme Council allowed. Although Turkish forces had been ordered by the Ottoman authorities not to resist the Greek invasion, violence did break out in Smyrna involving both soldiers and civilians. A thunderstorm halted the rampage but only after some 200-300 Turks and 100

2 The Jewish population was descended from Sephardic Jews who had been expelled from Spain, or had fled, as a result of persecution by the Spanish Inquisition under the first Inquisitor General, Tomás de Torquemada, at the close of the fifteenth century.

3 The Greeks of Smyrna were Byzantine Greeks or Romanos, having become distinct over the previous century from the Greeks, or Hellenes, who lived in Greece.

4 Also spelled Burnabat and Buja in English sources. The original name of Bournabat was from the Persian Birunabad meaning 'outside a town or city'. The name is difficult to pronounce in Turkish and was changed to Bornova. Source: Yildiz Belger, "Burnabat," 13 January, 2000, personal email (13 january, 2000). 
Greeks had been killed. ${ }^{5}$ After the initial trauma and excitement of the takeover, life in Smyrna went on relatively unchanged although different warships were in the harbour and different flags flew on the public buildings.

Mustafa Kemal was eventually recalled to active service by the Sultan and sent to Anatolia with wideranging powers as Inspector General of the 3rd Army. Modern Turkish history is said to begin on May 19, 1919, the date of Kemal's landing at Samsun in northern Anatolia. Soon after landing he told the Anatolians that the Sultan was a prisoner of the Allies and he began the process of establishing a provisional government based at Angora (now Ankara), headed by the Great National Assembly of which he was first President. He resigned from the army in July to avoid dismissal, having ignored all orders from the Sultan recalling him. The Ottoman Empire eventually signed a peace treaty in July 1920. By the Treaty of Sèvres Armenia was declared independent, while Greece was given land in western Anatolia, centered around Smyrna, and control of a number of offshore islands. Kemal refused to accept this treaty and determined to create a modern, secular Turkey, with its borders at the 1918 status.

Although France and Italy (both of whom had also occupied parts of southwestern Anatolia) maintained a military presence on the coast, Greece alone had ideas of an offensive against Ankara. It was clear to Kemal that, to accomplish his objective of restoring the borders, he would have to negotiate with France and Italy while defeating the Greeks in the west and the new Armenian state to the east. He began with an attack on Armenia. With the duplicitous military assistance of the Russian Bolsheviks, he conquered that country in October and November of $1920 .{ }^{6}$ By the treaties of Alexandropol (1920) and Moscow (1921), Turkey's eastern borders were secured and the Soviet Union became the first country to recognize the new Turkish nationalist regime. The state of Armenia ceased to exist after four brief months and Kemal was then free to turn his attention to the west.

Encouraged by the Supreme Council the Greek Army began a major offensive in June 1920 aimed at the capture of Ankara. Kemal replaced his western commander, Ali Fuat, with Ismet Pasha, who would later succeed Kemal as president of Turkey. Ismet stopped the Greek advance at the Inönü River on January 10,1921. He met them again at the same place when the offensive resumed in March and the battle raged for days before the Greeks broke off the engagement. The Greeks began a third major offensive in July, forcing Ismet back to the Sakarya River, close to Ankara. Kemal's enemies in the Great National Assembly, sensing a Greek victory, invited Kemal to take over the command of the army. Kemal accepted under the condition that he be given total authority, and assumed the role of commander in chief on August 4. He stopped the Greek advance for the last time at the Battle of the Sakarya River (August 23-September 13) and, a year later, began his own offensive on August 26, 1922. The year's grace heralded a significant change in Allied solidarity. Italy, on March 21 1921, had signed a separate treaty with the Ankara government, and France followed suit with a secret agreement on October 201921 . Both countries withdrew their forces from Anatolia in exchange for promised post-war economic concessions. ${ }^{7}$ Greece was left alone in Anatolia to face Kemal and no longer had the backing of the Supreme Council. The agreement with France not only released 80,000 Turkish troops from watching Cilicia, but also French munitions and supplies sufficient for 40,000 men were given to Kemal. Greece may have pondered that Byron's words of a century

5 Housepian, The Smyrna Affair, 50.

6 Norman Itzkowitz, "Atatürk, Kemal" in Encyclopcedia Britannica Online, <http://www.eb.com/eb/article?eu=117163>

7 Housepian, The Smyrna Affair, 79. 
earlier about the quality of French support - But Turkish force, and Latin fraud, Would break your shield, however broad - were indeed prophetic. ${ }^{8}$ Great Britain continued to provide Greece with financial support but, possibly because of the return of the presumed pro-German King Constantine to the Greek throne, became officially neutral.

\section{THE LIBERATION AND DESTRUCTION OF SMYRNA}

It had taken the Greek Army three years to advance to the Sakarya River but Kemal's offensive took only two weeks to push it back to the sea at Smyrna. The initial attack, catching the enemy by surprise, destroyed five Greek divisions and took 50,000 prisoners. The retreat quickly became a rout as the disorganized remnants of the Greek army fell back on Smyrna. As it retreated, the Greek army razed the countryside and destroyed the villages, forcing the surviving civilians, Greek and Turkish, to follow them. On the first of September the Greek wounded began arriving in the city, seizing whatever means of transportation were available. For eight more days the fleeing soldiers came in, desperate to reach the Greek warships in the harbour, followed by some 30,000 civilian refugees a day. Despite this influx of wretched humanity there was evidence that Smyrna remained quiet and peaceful until the Greek general staff and civil administration left on September 8. The British, French and Italian consuls had given formal assurances to the Armenian and Greek populations that their lives were not in danger. These assurances were to some extent believed, perhaps because Smyrna had been spared the deportations in 1915 and had remained relatively peaceful under the Greek administration. However, the wealthier members of these communities had already prudently left the city. The last Greek ship left the harbour on the early morning of September 9, a few hours before advance elements of Kemal's pursuing army, Şerefeddin's cavalry, entered the city. The harbour remained full of ships, including twenty-one British, French, Italian, and American warships and flotillas of smaller boats. They hoped to preserve order until the Turkish takeover and to protect the lives and property of their nationals.

As it transpired the Turkish takeover did not bring order. At the time Serefeddin is reported to have told an American intelligence officer, using French as a common language, that Armenian fanatics had made three attacks on his cavalry as they rode into Smyrna. ${ }^{9}$ However, something may have been lost in the translation. Two years later he stated under oath that the first two attackers were unknown and the last was a Greek soldier in uniform. ${ }^{10}$ Kemal entered the town on September 10, issuing an order that any Turkish soldier found molesting civilians of any nationality would be summarily executed. Nonetheless, the following morning 'Turkish troops surrounded the Armenian quarter and Turkish inhabitants were advised to leave. Shortly thereafter the Turks, soldiers and civilians, began a systematic orgy of murder, rape and looting. Within a very short time all the Armenian inhabitants had been

8 Lord Byron, Don Juan, Canto II!, verse LXXXVI, "The Isles of Greece", verse 14.

9 Housepian, The Smyrna Affair, 104.

10 In 1924 Şerefeddin was called as a witness in a lawsuit between the Guardian Assurance Company and the American Tobacco Company in London. This was a test case to see if insurance companies, who refused to pay for damages suffered in the destruction of Smyrna because they claimed a state of war existed, were liable or not. The tobacco company maintained that the war was over and the fire was a natural disaster. The case was decided in favour of the insurance company. Housepian, The Smyrna Affair, 220-23. This judgement was unsuccessfully appealed. Lloyd's List Low Reports, 22 (May 21 1925): 37-49.

11 Housepian, The Smyrna Affair, 119. Housepian suggests that Chrystomon's French military escort was powerless to help him. Smith, Ionian Visions, 308, states that Chrysostom was escorted by Turkish troops but that his murder was witnessed by helpless French troops. Others do not mention a French presence at all, e.g. George Horton, The Blight of Asia (Indianapolis: Bobbs-Merriil, 1926), 135-36. Smith's version is confirmed by a number of eyewitness accounts. See René Puaux, Les derniers jours de 5 myrne (Paris: 1923), 21 and Lysimacos (Economos, The Martyrdom of Smyma and Eastern Christendom (London: Allen \& Unwin, 1922), $110-13$. 
murdered, were in hiding or were crushed in the mass of other refugees on the docks. Vengeance was also visited on the Greeks. The Metropolitan, Chrysostom, was murdered by the mob at the instance of 1st Army Commander Nureddin Pasha, named that day governor and military commandant of Smyrna. ${ }^{11}$ Nureddin also arrested Greeks, Armenians and even Turks who were alleged to have cooperated with the Greek administration. These individuals were subject to court martial and summary execution. The international press reported that the looting and unrest in Smyrna was caused by Greeks, Armenians and Turks before the entry of the Turkish troops, and emphasized the discipline of the Turkish troops to reassure their readers. Nonetheless the European consulates began to advise their subjects to stay near the ships in the harbour.

In the morning of September 13 the wind from the Armenian quarter of Smyrna shifted away from the Muslim quarter and blew north towards the sea. Within an hour several fires had broken out. The fire spread rapidly and blazed for days, destroying large sections of the city. Many perished both in the conflagration and in encounters with the military. Survivors were driven down to the quays, where they huddled hoping to be taken off by the ships. Nationality played a large role in who was saved at this early juncture, since the neutral powers could not legally evacuate Turkish citizens. The result of the fire was that large sections of the old city - the Armenian, Greek and Frankish quarters - were destroyed and the non-
Turkish population was virtually eliminated through death or flight. Only the Turkish and Jewish quarters remained untouched. ${ }^{12}$ When a new, modern and wholly Turkish city was built, beginning in 1924 , on the ruins of Smyrna, it was known only by its Turkish name of Izmir. Smyrna was no more.

The question of who was responsible for the great fire has been debated for decades. At the time the Turks stated that it was the Greeks or Armenians, whom they often referred collectively to as Christians. Kemal told the French commander, Admiral Dumesnil, that Armenian incendiaries started it. ${ }^{13}$ These explanations had some plausibility since the Greek army had been ordered to destroy towns and villages as they retreated rather than let them fall into Turkish hands. Many commentaries of an inferential or deductive nature were published showing the improbability of Turkish responsibility. ${ }^{14}$ The general theme of these commentaries was that Turks would have no interest in destroying what was their own property and that Turkey had always been tolexant to non-Turkish Ottoman citizens. These views naively overlooked both the extreme anger that the Greek occupation had aroused in the Turkish populations and the enormous differences between the large multi-cultural Ottoman Empire and the ethnic nationalism of the new modern Turkey of the Kemalists. ${ }^{1.5}$

At the same time credible and contrary independent eyewitness accounts were published asserting that Turks started the fire and committed many other

Puaux was himself a refugee while CFconomos' book is extracts from dozens of newspapers, chiefly British, including eyewitness reports and interviews.

12 The bulk of the Jewish population left Smyrna subsequently as a result of post-World War II discriminatory taxation measures, aimed at non-Turkish residents, as well as cultural pressures and the desire to live in the new Jewish homeland. Housepian, The Smyrna Affair, 117.

13 Patrick Balfour (Baron Kinross), Ataturk: a Biography of Mustafa Kemal, Father of Modern Turkey (New York: Morrow, 1965), 370.

14 For example, see Abdullah Hamdi, "The burning of Smyrna", Current History (November, 1922): 317; Rachid Galib, "Smyrna during the Greek Occupation", Current History (May, 1923): 319, and James A. Sproule, "Who burned Smyrna?" Islamic Review XI (1923): 280-84.

15 Resat Kasaba, "Izmir 1922: A Port City Unravels", in European Modernity and Cultural Difference from the Mediterranean Sea to the Indian Ocean, 1890's-1920's, ed. J.H. Clarke (N.Y.: Columbia University Press, forthcoming): Typescript, 28. Citing speeches from the Grand National Assembly Kasaba makes it clear that the Greeks, Armenians and other foreigners were outsiders in terms of the nationalist movement, and that the new state was for Turks. See also Kemal's own view infra note 157. 
atrocities. René Puaux, after being evacuated to Malta, met with six other European survivors - "M. Herbert Whittal [sic] senior, ${ }^{16}$ Robert Hadkinson et son fils, I. Epstein, et les trois chapelains anglais de Smyrne, Bournabat et Boudja ${ }^{17 \prime \prime}$ - in the LieutenantGovernor's house and prepared depositions, subsequently published, ${ }^{18}$ that clearly showed in their view that the Turkish military was responsible for the fire. Puaux later published a pamphlet including even more comprehensive testimony gathered from eyewitnesses. One of these "certifie avoir personnellement vu des Turcs soldats et civils [sic] mettre le feu au moyen de benzine, pétrole et dynamite" and everywhere the story was the same. ${ }^{19}$ George Horton, the American consul in Smyrna, wrote a memoir from his own observations and testimony he gathered in which he concluded "the destruction of Smyrna was but the closing act in a consistent program of exterminating Christianity throughout the length and breadth of the old Byzantine Empire." 20 Horton was a reliable witness to events, but his interpretations were always reduced to the religious terms of Islam versus Christianity. He seems to have misunderstood the nature of Kemalist nationalism, and been unaware that, at this time, Kemal was planning a secular state and the end of the Caliphate. Another American observer ascribed a gentler motive suggesting that the Turks burned Smyrna as a result of Armenian resistance and refusal to hand over arms. ${ }^{21}$

Despite these eyewitness accounts, the people and governments of the West did not criticize Turkey for the tragedy of Smyrna in the same way that they had castigated the Ottoman government for the destruction of Chios exactly a century earlier. So great was western admiration for Kemal and the new Turkey that it seemed people wanted to believe in some other cause of the fire. One over-written and underresearched biography of Kemal had the Gazi coming too late to prevent the Greeks destroying Smyrna, finding the city in flames as he arrived in the hills above it. ${ }^{22}$ Until relatively recently even the more scholarly and reliable sources suggested that the fire's origins have never been satisfactorily explained..$^{23}$ The western governments, seeking for economic concessions and trade advantages, had no interest in embarrassing Kemal. The destruction of Smyrna was forgotten after a while in the shadow of greater events. The silence ended in the 1970s when carefully documented studies opened the question again. One modern historian described this re-opening of the case as follows:

Most spectacular (and subject to the most careful coverup) was the Kemalist conquest of Smyrna (Izmir), on 9 September 1922, which was followed by looting, rape

16 Herbert Octavius Whittall (1858-1929), a partner in C. Whittall and Co.

17 The British chaplain of St. John's, Smyrna was Charles James Hamilton Dobson, a New Zealander who had served with the N.Z.E.F. (1914-1920). He was transferred from New Zealand to Smyrna in 1922. Lucius George Pownall Fry had been the chaplain of St. Mary Magdaiene's, Bournabat from 1919. Robert Pickering Ashe had been chaplain of All Souls', Boudjah from 1898. While Dobson and Fry never came back to Turkey, Ashe did return to Boudjah (1924-1925). Source: Crockford's Clerical Directory, 1923 and 1927.

18 Gibraltar Diocese Gazette, VI, no. 2 (November, 1922).

19 Puaux, Les derniers jours de Smyrne, 15-23. See also the harrowing account in the diary of Armenian doctor Garabed Hatcherian, An Armenian Doctor in Turkey: Carabed Hatcherian: My Smyrna Ordeal of 1922, edited by Dora Sakayan (Montreal: Arod Books, 1997).

20 George Horton, introduction to The Blight of Asia (Indianapolis: Bobbs-Merrill, 1926).

21 Oran Raber, "New light on the destruction of Smyrna," Current History (May, 1923): 312-18.

22 Ray Brock, Ghost on Horseback: the Incredible Atatürk (N.Y.: Duell, Sloan and Pearce, 1954): 271-74.

23 Kinross, Atatürk, 370 
and murder by the Turkish forces, and by setting fire to the Greek and Armenian quarters. For decades afterwards the myth was fostered that the Greeks and Armenians had set fire to their own areas before quitting them - an untruth, recently (and finally) exploded in a book by Marjorie Housepian. ${ }^{24}$

Housepian's book, based largely on eyewitness accounts and unpublished primary sources, certainly seems definitive in proving that uniformed soldiers were involved in setting the initial fire. However, it should be noted that Kemal's army had a significant number of irregular soldiers recruited largely from Anatolian bandit groups. The irregulars traveled and fought with Kemal's armies, but were less disciplined and far harder to control than the regular troops. ${ }^{25}$ Housepian, amongst others, makes no distinction between the regular and irregular soldiers assuming they should all have been under military discipline and orders. None of these modern sources appear to mention the fact that, three days before the fire started, the irregular troops were disbanded in Smyrna by a proclamation of September 10 that stated:

The patriotic volunteers, who participated by action during the march on Smyrna, must immediately leave for their respective normal occupations... All the people who joined the army voluntarily, for love of country, shall return to their homes. ${ }^{26}$

It is quite clear that the irregular troops remained in Smyrna and its environs for a considerable period of time. It is possible they may have been responsible for some of the incendiary activity while not under military discipline. Therefore, while the fire almost certainly started as a result of military activity against targets in the Armenian quarter, the disbanded irregulars and elements of the local Turkish population could well have caused other fires during their looting and pillaging rampages.

\section{THE WHITTALLS OF BOURNABAT}

While many sources have examined what happened to Smyrna, little has been written about the beautiful suburb of Bournabat that was all but destroyed at the same time. Bournabat was a little Turkish village when Europeans, working in Smyrna, began to reside there in the early part of the nineteenth century. It became the prototypical Utopia that the Englishman abroad would build if he had sufficient wealth, a plentiful supply of servants and the ideal climate. It was noted for its large villas and huge walled gardens where many exotic plants bloomed. It was said that in Smyrna one could always tell when the train from Bournabat came in from the smell of jasmine brought by the commuters for their city friends. The European community, largely of English and French extraction, was small and cosmopolitan, with much intermarriage between the various nationalities. The Turkish soccer team for the Intermediate Games of the IV Olympiad in Athens (1906) was made up of young men from Bournabat and their names give a clue to the cultural diversity of the village: Edwin Charnaud

\footnotetext{
24 Christopher Walker, Armenia: the Survival of a Nation (N.Y.: St. Martin's Press, 1990): 345. Indeed most scholars consider Housepian's work conclusive. Lord Kinross, the biographer of Atatürk who had himself said in 1965 that the fire's origins had never been satisfactorily explained, said of Housepian's work: "A contribution to modern history of distinct value. Only now, 50 years later, does a writer lift the smokescreen from the dead ashes of Smyrna." <http://ftp.phish.net/herald/issues/111998/ smyrna.f.html>. Michael Llewellyn Smith, Ionian Visions: Greece in Asia Minor (1998), reached the same conclusion as Housepian apparently independently. Smith, appointed Ambassador to Greece in 1996, based his monograph on his doctoral thesis. Neither the original monograph in 1973 nor the revised edition of 1998 makes any mention of Housepian's work, which was first published in 1966.

25 Kasaba, "Izmir 1922,", 25-26.

26 Lloyds Law List Reports, 45.
} 
(goai), Zaren Kuyumtzian, Eduard Giraud (fullbacks), Jacques Giraud, Henry Joly, Percy de la Fontaine (halfbacks), Donald Whittall, Albert Whittall, Godfrey Whittall, Herbert Whittall, Edward Whittall (forwards). ${ }^{27}$ The European community enjoyed special privileges under the Ottoman Empire, including the right to have their own law courts arbitrate disputes. The male-only social centre of Bournabat was the Club (or English Club), a house on the main village square that had a meeting room, card room, and billiard room, and was a place where the gentlemen could drop in for a meal and a drink of an evening. ${ }^{28}$ Finally to add an aura of adventure and excitement to this idyllic setting, the roads around Bournabat were "haunted with a suspicion of brigands".29

The Whittalls were an important Bournabat family whose members play a major role in this narrative. ${ }^{30}$ In 1999 Ozdem Sanberk, the Turkish Ambassador to Great Britain, wrote:

For the last hundred and ninety years, there has been a very special bond linking Britain and Turkey. It is the Whittall family. The history of the Whittalls is more colourful and exciting than many adventure stories and it is the history of Turkey and its advance into the modern world economy. ${ }^{31}$

Charlton Whittall (1791-1867) first went to Smyrna in 1809 as a representative of Breed \& Co. ${ }^{32}$ In 1811 he formed C. Whittall \& Co., an exporter of a number of commodities especially dried fruit, and the following year he was admitted as a member of the Levant Company. In 1817 his brother James (17981836) joined him. Charlton married Magdaleine Giraud, the daughter of his landlady, in the first of many marriages between the families. So successful was Charlton as a businessman that in 1863 he received a visit from the Sultan, unheard of for a foreign merchant at the time, and was awarded the Imperial Order of the Medjidiye (4th class). ${ }^{33}$ He built the church of St. Mary Magdalene in 1857, donating it to the Protestant community and taking care of its permanent upkeep in his will. ${ }^{34}$ An English traveler visited Whittall in the Big House ${ }^{35}$ at Bournabat, and wrote:

27 The players are listed at <http://www.risc.uni-linz.ac.at/non-official/rsssf/tables/ol1906f.html>. Giraud was erroneously spelied Girard, and there are other questionable spellings such as Eduard.

28 Ray Turrell, Scrap-book, 1809-1922 (Englefield Green: Richard Bell, 1987): 145.

29 Emily Pfeiffer, Flying leaves from East and West (London: Leadenhall Press, 1885): 4.

30 Sources for information about the Whittalls and Bournabat are the following: 1. Richard Wookey, Fortuna (Toronto: Macfarlane, Walker and Ross, 1998); Descendants of the Whittalls of Turkey Family Reunion Programme (London: Imperial College, 1999), especially "Whittall Family History", 4-6; Mary Whittall, A Book of Thoughts: Memories of my Childhood in Turkey (Calgary: 1996); Edmund Giraud, Family Records: a Record of the Origins and History of the Giraud and Whittall Families of Turkey (London: Adams and Shardlow, 1934); Betty and Paul McKernan, The Genealogy of the Whittall Family of Turkey (Privately printed, 1996); Evelyn Lyle Kalças, Gateways to the Past: Houses and Gardens of Old Bornova (Bornova: Bilgehan Matbaasi, 1978; and interviews with Marjorie Close, Mary Whittall and I.R. Wookey.

31 Descendants of the Whittalls, 3. The Ambassador was expressing his regrets at being unable to attend this huge reunion.

32 The 1809 date is given in most published sources including Edmund Giraud, Family Records. However. Giraud's grandson Brian Giraud claims to have proof that Whittall first came to Smyrna in 1812. Sally Gallia, "Whittall and Smyrna", personal email, 18 May, 2000 .

33 "Whittall Family History", in Descendants, (supra note 30), 4-5. The sultan's visit is described in some detail by Whittall's sonin-law. Sir Henry F. Woods, Spunyarn: From the Strands of a Sailor's Life Afloat and Ashore (London: Hutchinson, 1924), 2: 68-70.

34 Giraud, Fomily Records, 73, 79. The name was chosen because his brother's wife's name was Mary and his own wife's name was Magdaleine. While Giraud states Whittall's will took care of the permanent upkeep, Sally Gallia states that the chaplain is unaware of any such provision.

35 Originally built as a Dutch convent, the Big House still exists and is the residence (Rektölük) of the Rector of Ege University. Kalças, Gateways to the Past, 19 (supra note 30). It can be seen on the Ege University webpage: <http://www.ege.edu.tr/egeweb/ binalar/rekorluk_ust.jpg>. Sally Gallia reports that the Rektölük is now the administrative headquarters of the University. 
I have been passing the last ten days with a great Merchant Prince and a pleasant little tribe of Wandering Britons at the charming village of Boumabat. We have had laughing rides and moonlight walks; I have been drinking in the words of experience from as noble-hearted and cheery an elderly gentleman as ever did honour to our national name in a far-offland; and who has written his own in indelible characters enough all over the country - now in a road, an hospital, or a college; now in the living, brighter page of poor men's hearts. It does one good sometimes, at least, to meet those hale, happy worthy folk who go about doing good, and are a living blessing to their dwelling place-kind, gentle, warm-hearted people, whom the world has not been able to teach its selfish wisdom, whose minds are as fresh and guileless as at nineteen, and who are all the better for it. ${ }^{36}$

Chariton's son, James, ${ }^{37}$ had thirteen children, including Sir James William Whittall (1838-1910) who became the patriarch of the Constantinople (Moda) branch of the family. ${ }^{38}$ Indeed all the Whittalls had large families and by the turn of the century controlled substantial business interests in Anatolia. On March 11 1902, the famed traveler, archaeologist and Arab administrator Gertrude Bell wrote from Smyrna to her stepmother, Lady Florence Bell:

These are most delightful people. Helen Whittall, the girl I met in the train, came to fetch me at 11 and we journeyed up here together... Mr Whittall ${ }^{39}$ joined us and there were also troops of cousins, for they all live out here. The house is a great big place, with high enormous rooms, set in a garden 200 years old across which a line of splendid cypresses runs. The old mother of the tribe, $\mathrm{Mr}$
Whittall's mother, lives here, a very old woman who kissed me when I came in. We lunched, after which we walked about in the garden gathering bunches of roses and violets. Mrs Herbert Whittall is a very nice sweet woman, and the girl Helen a dear. It was a stormy day with sudden bursts of rain and bright sun between so we did nothing more until we had had a cheerful schoolroom tea, after which Mr and Mrs Whittall and I went to see a brother of his, Mr Edward Whittall, who is a great botanist and has a most lovely garden. He collects bulbs and sends new varieties to Kew and is well known among gardeners - an interesting man too, for he is the Vali's ${ }^{40}$ right hand and is consulted by him on all matters, a thing unknown before they say. But these people get on with the Turks. The old Sultan, uncle of Abd ul Hamed stayed in this house; it is the only private house which has received a Sultan. We found Mr E. Whittall tying up his pelargoniums; he took us all round his garden and then out into a big garden above the village where he grows bulbs for the European market and makes experiments with them. There were ranks and ranks of narcissus and daffodils and hyacinths flowering and we came away with a bundle of them. We had a long talk about irises and daffodils and next Tuesday I am to come back here and go with him to the top of a mountain where he has his hill garden for wild bulbs. I think it will be enchanting.... In the dining room here are all the family portraits, bad as pictures, but most interesting as types. On one side the grandfather of Mr Whittall who was the first to come out, a stern old man in a stock, and all his sons and grandsons flanking him. On the other side his wife, a Venetian, one of those Venetians who lived in Constantinople and were driven out by the Turks and settled first in Crete, then in Athens, then here; and her

36 Eustace Clare Grenville Murray, Turkey: being Sketches from Life by the Roving Englishman (London: George Routledge, 1877): pp. 300-301. A footnote identifies the merchant prince as Charlton Whittall.

37 James Whittall (1819-1882), known as James of the Big House, was a well-known collector of Hellenic and pre-Hellenic coins of Asia Minor, and his collection is now in the British Museum.

38 Sir James founded J.W. Whittall \& Co. of Constantinople in partnership with Sydney La Fontaine. The company went into voluntary liquidation in 1969, becoming Vitsan A.ş. Whittall was so well thought of that on his death the street where his business was located was renamed "Whittal Çikmazi". Vitsan A.Ş. homepage <http://www.yore.com.tr/vitsan/vitsan1.html>

39 Richard Watson Whittall (1847-1920).

40 Kamil Pasha (1832-1913). 
mother who was an Italian, a Capo d'Istria, both women wearing a semi Oriental costume; and their men folk in 18 th century clothes. ${ }^{41}$

On a subsequent visit, five years later, she wrote:

My preparations are really all finished but I have to wait and hear about the head man for my diggings whom $\mathrm{Mr}$. Richard Whittall ${ }^{42}$ is engaging for me. As this is the most important matter of all I cannot leave without settling it. Then to call on all my Whittall friends. They have the bulk of the English trade in their hands, branch offices all down the southern coast, mines and shooting boxes and properties scattered up and down the S.W. coast of Asia Minor and yachts on the sea. They all have immense quantities of children. ${ }^{43}$ The sons, young men now in various. Whittall businesses, the daughters very charming, very gay. The big gardens touch on one another and they walk in and out of one another's houses all day long gossiping and laughing. I should think life presents itself nowhere under such easy and pleasant conditions. ${ }^{44}$

Three of James' eight sons became partners in C. Whittall and Co. - Richard Watson Whittail, Edward
Whittall (1851-1917) and Herbert Octavius Whittall. Edward purchased a fine house standing in a sevenacre walled garden in Bournabat from the Corpi family. ${ }^{45}$ He interested himself in local matters of public welfare and built the dam that brought fresh water to the village. ${ }^{46} \mathrm{He}$ was, as Gertrude Bell noted, a keen amateur botanist who rambled the local hills looking for local flora and regularly sent specimens to Kew Gardens. He hired numerous locals ${ }^{47}$ to help him search for botanical specimens and to tend to the special gardens he had built up in the hills to develop new varieties of plants. For this reasons he was as well known to the Turk and Greek villagers as he was to the Europeans and the Smyrna merchant community. His business was the export of dried fruits. Whittall had five sons, - Edgar, Albert, Godfrey, Edward and Walter - and four daughters, - Elsie, Ray and the twins Ruth and Jessie. ${ }^{48}$ Like other Whittalls, he remained staunchly English and his sons were sent to England to go to school.

Bandit activity was a feature of Western Anatolian life in the nineteenth and early twentieth centuries, and the kidnapping of wealthy residents was always a danger. One English visitor to Bournabat was

41 The Robinson Library, University of Newcastle, has published these letters on their website at <http://www.gerty.ncl.ac.uk/ letters/1517.htm>. A number of letters describe Bornova and its major families. Extracts from the 1902 correspondence can be found in Turrell, Scrap-book, 1809-1922, 40-41.

42 Possibly Richard Watson Whittall, but more probably his son Richard James Whittall (1869-1919).

43 For example James, of the Big House, had thirteen children and ninety-one grandchildren.

44 Gertrude Lowthian Bell, The Letters of Gertrude Bell, edited by Lady Bell (London: Ernest Benn, 1927), I: 228.

45 Giraud, Family Records, 82. Although much of the land in Bornova was expropriated to build Ege University, Whittall's property still stands. The family still lives there (currently Godfrey Giraud's widow, Gwynneth Reggio Giraud) on condition they maintain the gardens, considered something of a local treasure. The original owner of the house was an unknown French man who came at the time of the revolution. René Savary, Duc de Rovigo, Napoleon's Chief of Police, lived there from 1816-1819 after his escape from imprisonment in Malta.

46 After the Turkish liberation of Smyrna, the dam was not maintained. It burst in 1928 flooding the village of Bornova. "After the Turks took over, with typical Eastern philosophy of not maintaining anything, the dam finally collapsed and the ensuing flood of water could not be contained by the torrent bed and all the village was flooded. I was away at school at the time so missed the excitement." Mary Whittall, A Book of Thoughts, 10.

47 In 1893 he had about fifty locals working for him seeking bulbs. Letter to Kew Gardens quoted by Turrell, Scrap-book, 1809$1922,44$. Turrell also cites correspondence ( $p .42)$ from Peter Davies about the very real concern that Whittall's activities would seriously damage local bulb populations. A number of species were named after him including the Fritillaria Whittallii. Ray Desmond, Dictionary of British and Irish Botanists and Horticulturalists including Plant Collectors and Botanical Artists (London: Taylor and Francis, 1977): 657. Wookey, supra note 30, p. 18 states that Whittall was the second largest supplier of plants in Kew Cardens' history. 48 Jessie (1884-1928) married Reginald Turrell, and one of her three daughters is Ray Turrell Bell. 
appalled that a woodcock shoot was organized on a Sunday, a thing simply not done on the Lord's Day in England, until he understood the hunt was a pretext to carry shotguns while walking in the hills. ${ }^{49}$ In 1855 James McCraith (1810-1901), a former Royal Naval doctor who worked at the British Maritime Hospital, Smyrna, spent a week in the hands of brigands until Charlton Whittall paid his ransom. ${ }^{50}$ Edward Whittall became involved with Çakici (or Çakircali) Mehmet Efe (1872-1911), ${ }^{51}$ the most famous of all the Anatolian bandits. While Çakici robbed trains and small caravans, his preferred practice was to kidnap wealthy merchants and landowners. He concentrated on Albanians, whom he detested, and Greeks. ${ }^{52}$ Since he distributed some of the ransom proceeds amongst the poor, he gained the reputation as something of a Robin Hood and was the subject of many songs. Edward Whittall apparently met Çakici through the anglophile governor (or Vali) of Aydin, Kamil Pasha and his son, Sait Pasha, although Whittall had probably employed a number of Çakici's band from time to time. ${ }^{53}$ Since Whittall was known and trusted by the bandits and the authorities, he was used as an intermediary in at least one of Çakici's kidnappings, that of Pavli, a rich Greek landowner. Some sources go so far as to say that Sait Pasha received a percentage of the proceeds from the ransoms and robberies. ${ }^{54}$ It is also alleged that the Whittalls and other Levantine families in Bournabat provided Çakici with more modern shotguns, as a result of which he was always better equipped than the Ottoman police forces.

Whittall, at the instigation of Kamil Pasha, also played a key role in a pardon offered to Cakici by the Ottoman government. ${ }^{55}$ This was one of three such pardons offered to Çakici during his 15 -year career. The offer of free pardons or safe-conduct negotiations was apparently a standard bandit-catching technique of the Ottoman authorities, and was how Çakici's father, Çakici Ahmed Efe (1824-1883) met his end. ${ }^{56}$ Given this family history, it is unlikely Cakici would have been tricked into surrendering. One source, evidently from the Perfidious Albion school and unable to believe in Whittall's botanical passion, attributes a more sinister motive to his involvement with Çakici. It is said that the British government, fearful of the collapse of the central Turkish government, determined to seek local allies and used the Whittalls in this endeavour. It continues that an employee of Whittall's went into the

49 John Presland (pseud. of Gladys Skelton), Deedes Bey: a Study of Sir Wyndham Deedes 1883-1923 (London: Macmillan, 1942): 90-91.

50 James McCraith, McCraith among the Brigands of Smyrna (Dublin: Porteous and Gibbs, 1874). Partly reproduced in Turrell, Scrapbook, 1809-1922, 165-74.

51 Efe is a title, often given to Anatolian bandits, meaning a brave, strong, generous man. Çakircali means "Blue-green eyed". 52 Seref Üsküp, Çakici Efe (Izmir: Hür Efe Matbaasi, 1975): 132-34. Summary translation provided by Yildiz Belger. Üsküp, a native of Ödemis, based his work of interviews with those who had known Çakici personally as well as Çakici's children and grandchildren by his three wives. In this context Albanians are Moslem Turks who were displaced during the Turco-Russian War (1877-1878) and, later, in the struggles that preceded Albania's independence in 1912. The Ottoman government employed many of these Albanians in the army, in the police force and as tax collectors. One of the police chiefs, Hasan Cavus, lured Çakici's father to his death. Üsküp, 60-61.

53 Üsküp, Çakici Efe, 61.

54 Ibid., 61-62, 94-95, 182. Belger (supra note 52) suggests this allegation is quite implausible since Sait was extremely wealthy in his own right and his family had a long history of public service to the Empire. Yildiz Belger, personal email, 2 December, 1999.

55 Halil Dural, Bize Derler Cakirca: 19. ve 20. Yuzyilda Ege'de Efeler [trans. They call us Cakirca: The Efe in the Aegean in the 19th and 20th centuries] (Istanbul: History Foundation of Turkey, 1999): 140-142,151. Summary translation provided by Leyla Neyzi. Leyla Neyzi, "They Call Us Calirca," personal email, 2 December, 1999. Dural, a schooiteacher, now deceased, based his book on documentary research and oral histories.

56 Üsküp, Çakici Efe, 10-14. 
mountains ostensibly to collect flower bulbs, while his real purpose was to communicate with Çakici. This employee, Kosta from Bornova pretended to be a member of the bandit group using the name Osman, but was in fact a Whittall spy. The Whittalls, while working to secure Çakici's pardon, were attempting to control his activities through this spy. ${ }^{57}$

There are variant versions of how Çakici met his end. Though protected by Kamil and Sait, it is said other Ottoman authorities, rival factions in the local governments, continued to pursue him. ${ }^{58}$ One story is that Çakici was captured, killed, skinned, torn to pieces and his decapitated body suspended by one of its feet in front of the governor's mansion in Nazilli, on Nov 17,1911 . This was part of the campaign by the Ottoman government to restore order and to reinstitute state authority in the area. The reason why he was killed so violently was to "prove" to the local populace that he was not invincible..$^{59}$ Other versions state that Çakici was shot and killed on Karincali mountain, but vary as to whether this was as a result of a clash with Ottoman police or an accident involving his own men. Identification of the body, which was not found until 1912, was difficult because the hands and head were missing. This was apparently the custom amongst bandits when one, especially a leader, was killed in order to hinder identification and foster the myth of invincibility. ${ }^{(6)}$ Thus the same set of facts, the discovery of a decapitated body, can give rise to totally opposite interpretations, and the truth remains obscure.

During the First World War, the next generation of Whittalls stepped into prominence in Smyrna affairs. On his own initiative the British Director of Naval Intelligence, Sir William R. Hall, undertook to contact the Turkish authorities in order to purchase their neutrality prior to the Dardanelles campaign. He selected as a messenger a railway engineer, George Griffin Eady, and asked him if he had good contacts with the Turks. Eady replied, though he knew most of the important members of the government, the best person to approach would be Edwin Whittall, son of Sir James William Whittall. Eady and Whittall went to Athens on February 11915 and attempted to make contact with a prominent Turkish minister, preferably Mehmet Talaat Pasha (1874-1921) through the pro-British Grand Rabbi of Constantinople. ${ }^{61}$ At first Turkey demurred but, after the British began a naval bombardment on the outlying Dardanelles forts, agreed to meet Eady and Whittall at Dedeagatch. Eady offered Talaat $£ 3,000,000$ (he had authority to offer one million more) for Turkey to become neutral and open the Dardanelles to British shipping. He could not, however, offer the one thing that most authorities agree Turkey would have accepted - the guarantee that Constantinople would remain Turkish after the war. When Hall reported his initiative to the war cabinet, hoping to get more to offer the Porte, Winston Churchill, then First Lord of the Admiralty, was aghast at the amount of money Hall had offered. Hall stated that he felt it was a small price to offer for the control of the Dardanelles. Churchill turned to the First Sea Lord, Sir John Fisher, who said that they should save the money as his attack on the Dardanelles was imminent and they would gain control for nothing. Hall

57 Dural, Bize Derler Cakirca.

58 Ibid.

59 Kasaba, "Izmir 1922," 25, citing Sabri Yetkin Ege'de Eskiyalar (Istanbul: 1996): 172-73.

60 Üsküp, Çakici Efe, 311-23.

61 Ceoffrey Miller, Straits: British Policy towards the Ottoman Empire and the Origins of the Dardanelles Campaign (Hull: University of Hull Press, 1997): 470-75.

62 Eric Whittall was the oldest son of Charlton Frank Whittall, thirteenth and last child of James Whittall, and his first wife Ethel Barker. 
was ordered to have his agents break off negotiations after a couple more days. Whittall and Eady ended the talks on March 16, arriving at Salonica two days later just as the parsimonious Fisher's great and disastrous attack began.

At the same time as Edwin Whittall went to Athens, the British tried to ensure Smyrna remained an open port and not a threat. The Vali of Smyrna was Rahmi Bey, an anglophile and close associate of Eric Whittall (1887-1932), Edward Whittall's nephew and the Smyrna correspondent of the London Times. ${ }^{62}$ The American consul, George Horton, described Rahmi Bey in the following terms:

I soon discovered that the govemor-general had no faith in the final victory of the German-Turkish arms, and that he was extremely anxious to keep an anchor to windward. He was playing a double game; of keeping in at the same time with the authorities in Constantinople and with the prominent British, French and Italians at Smyrna. 63

In March 1915, to achieve their aims regarding Smyrna, the British navy threatened to bombard the forts around Smyrna (as they were doing to the Dardanelles forts) and stated that they could not guarantee there would be no damage to the town. This action would be extremely unpopular with the Greek government and destruction of these forts was not a practical military proposition. The Foreign Office persuaded the Admiralty to allow Sir Wyndham
Deedes, a former military attaché at the Constantinople embassy posted to the Smyrna consulate in 1913, to negotiate directly with Rahmi Bey to keep Smyrna a free port and to have the forts dismantled. Deedes knew Rahmi Bey well and had also been a frequent pre-war visitor to Bournabat, where he played golf and enjoyed the shooting. ${ }^{64}$ Deedes set up the meeting with Rahmi Bey through Eric Whittall. They met at Urla where Whittall and Charles Karabiber accompanied Rahmi Bey. ${ }^{65}$ Deedes' negotiating position was an extremely weak one, since the navy would be unable to carry out the threatened action. Rahmi Bey was not deceived by Deedes but, through the influence of Whittall and because of his own dislike of Enver Pasha's government, agreed that Smyrna would remain a free port for the duration of the war although the forts were not dismantled. ${ }^{66}$

Throughout the war Rahmi Bey continued to play a cautious game. From time to time he had leading Greek and Armenian citizens arrested and deported to the interior simply to satisfy the demands of the central government. ${ }^{67}$ However, he was always careful to protect the European residents despite their status as enemy aliens. Edward Whittall spent the last years of his life unmolested at Bournabat, even though he insisted with patriotic foolhardiness on flying the British flag over his house. ${ }^{68}$ James La Fontaine reports that he himself was released from internment "thanks to the efforts of Rahami [sic] Bey, the enlightened governor of Smyrna, whose extraor-

63 George Horton, Recollections Grave and Gay (N.Y.: 1927): 220-21.

64 Skelton, Deedes Bey, 90-91

65 Nurdogan Tacalan, Ege'de Kurtulus Savasi Baslarken (Istanbul: Karacan Yayinlari, 1970): 42-45; summary translation provided by Yildiz Belger. Charles Karabiber was a Romanos and a Turcophile. He was the Foreign Affairs Director in the Governor's Office. After the liberation he went to Paris instead of Greece, and for many years he worked there as a lawyer (p. 32).

66 Skelton, Deedes Bey, 152-54. Skelton does not mention Whittall by name in recounting this episode, although Whittall is reputed to be mentioned in Deedes' diaries for the period. Source: Sinan Kuneralp, personal email, 30 November, 1999. It is almost certain that Deedes knew Whittall from his Bournabat visits and, given their mutual friendship with Rahmi Bey, highly probable that Whittall was involved.

67 Housepian, The Smyrna Affair, 110.

68 Wookey, Fortuna, 14. 
dinary generous and considerate treatment of enemy subjects will ever be remembered by those who lived, during the war, in Smyrna." ${ }^{69}$ The gratitude of the European residents for this treatment took tangible form when Cerkez Ethem kidnapped Rahmi Bey's son, Alpaslan, from Miss Florence's school in Bournabat in February 1919. The European community paid the ransom and Alpaslan safely returned after 23 days of high adventure. ${ }^{70}$

From time to time the British would try initiatives to get the Ottoman Empire out of the war, but little interest was shown in these offers in the Porte after the failure of Fisher's offensive. This attitude changed, however, with the collapse of Bulgaria in September 1918. Turkey began to make vague and unauthorized gestures about the possibility of an armistice. ${ }^{71}$ Germany made an attempt to halt this process and, suspecting Rahmi Bey of "entente tendencies", persuaded the Porte to name him a Senator on September 25 and recall him to Istanbul. ${ }^{72}$ Rahmi Bey declined the honour and, on October 5 , sent a three or four person delegation including Edmund Giraud and Charles Karabiber to discuss an armistice with Lord Granville, British Minister in Athens. ${ }^{73}$ Although Granville communicated this to his government, it is suggested that the British were trying to complete the Mesopotamian campaign and seize Mosul, with its petroleum industry, before discussing peace. ${ }^{74}$ Therefore nothing came of the initiative and some reports suggest the "Smyrna Commission" was not allowed to land in Athens. ${ }^{75}$ A few days later the grand vizier, Ahmed Izzet Pasha, in somewhat unorthodox fashion, sent a high ranking British prisoner-of-war, Major-General Sir Charles Townshend, to Mudros to plead his case. ${ }^{76}$ However, the British insisted on an official delegation and, on October 26, the Minister of Marine, Rauf Bey, was sent to negotiate the peace. The armistice of Mudros was signed on October 31.

Rahmi Bey's strategy of "keeping an anchor windward' initially appeared to have availed him little at the war's end. In March 1919 Turkey was startled by an Allied demand for the arrest and apprehension of several dozen war criminals. ${ }^{77}$ Rahmi Bey was arrested for war crimes in connection with the Greek and Armenian deportations. Although the trial was a Turkish responsibility the government of Damad Ferid Pasha asked Britain to take care of the convicted prisoners. Rahmi Bey was therefore imprisoned on Malta in April 1920. However, his prudence in the treatment of foreigners and his friendship with the Whittalls continued to be rewarded. Eric's father, Charlton Frank Whittall (1864-1942), interceded on his behalf and secured his release in October 1921.

Edward Whittall's granddaughter, Mary Whittall, described Bournabat and the Whittall house in the following terms:

69 Giraud, Family Records, 143

70 Source: Mary Whittall who was attending this school at the same time. Alpaslan himself stated that the ransom was paid by Alanyalizade Mahmut Bey (who with Rahmi Bey's support had been elected president of the Smyrna Chamber of Commerce in 1909), Nazmi Tocuoglu and Harry Giraud. Tacalan, Ege'de Kurtulus Savasi Baslarken, 153. If this information is accurate it is still highly likely that Harry Giraud (1874-1963), older brother of Edmund Giraud and manager of the Oriental Carpet Company, Izmir, acted on behalf of the clan.

71 Busch, Mudros to Lausanne, 12-13.

72 Times (London), 9 October, 1918, p. $5 \mathrm{~d}$.

$73 \mathrm{lbid}$.

74 Tacalan, Ege'de Kurtulus Savasi Baslarken, 32

75 Times (London), 23 October, 1918, p. $5 \mathrm{~d}$.

76 Busch, Mudros to Lausanne, 15. 
Most big houses had their Bezoules or built in gossip circles at the end of the garden, on the square, or main road. The old people would take up their positions (or so it seemed to me) and passers by would join the group of aunts, uncles, cousins or grandparents. A friendly and leisurely procedure in which village gossip was passed from mouth to mouth. Granny Whittall's, ${ }^{78}$ whose garden was sheltered from view by a high wall, had a terrace overlooking the road. It was hidden from the house by a clump of bamboos and leading to it were two flights of stairs. Stone lions ornamented the more formal one and iron railings bounded the second one which led to a little bridge over a water way, running into a big pond snaking its way along the front of the house. Grandpa $W$. was a great gardener and his garden was a place of big and sometimes rare trees, as of formal gardens, kiosks, lawns, greenhouses and hidden corners - just a fairyland for us children. But more about the garden later, for it has had such an influence on my life and lies enshrined in my heart-a pearl of great price. ${ }^{79}$

Edward Whittall's daughter, Ruth, had married Edmund Giraud (1880-1960), the wealthy owner of a Smyrna textile factory. The war brought some friction between the Whittalls and the Girauds when the latter made uniforms for the Turkish army. There may have been other reasons for this friction since Giraud did not seem an altogether admirable character. Weak, vain and selfish by some accounts, he seduced his children's English governess, making her his mistress. He also enjoyed an unenviable reputation with servant girls. ${ }^{80}$ However, such lifestyles were not uncommon in the Levant. Giraud was certainly an able businessman, inheriting little and becoming a millionaire through his cotton factory and, after he lost everything in 1922, the Oriental Carpet Company. In September 1922 he was in London with his mistress, while his two older children, Godfrey and Edna, were at school in England. It was left to his brother, Charlie, ${ }^{81}$ to hire a boat to evacuate what family remained in Bournabat to Athens after the fire started. These included Ruth Giraud and her two small daughters, Mary (1911- ) and Margaret (1917- ). Mary returned to Smyrna after the fire, marrying a cousin Willem "Wem" Whittall, before emigrating to Canada in 1951.82

\section{THE FLIGHT OF THE EUROPEANS}

The liberation and destruction of Smyrna caused consternation in the Bournabat European community. Many sought the safety of ships in the harbour when the Greeks left, planning to disembark after the Turkish takeover. Others vowed to stay and protect their property. As the situation worsened more and more residents fled to the ships. The British authorities first advised their approximately 3,000 citizens, centred in Bournabat and Boudja, to seek safety in Smyrna and later, when the fire started, decided to evacuate all citizens at least to Malta. Other residents relied on their own resources to escape. Reginald Turrell spirited his family safely away on a commandeered ferryboat. ${ }^{83}$ Mary Whittall described the period ending with her evacuation as follows:

77 lbid., 166-67.

78 Edward Whittall's wife was Mary Maltass

79 Mary Whittall, A Book of Thoughts, 6-7. (supra note 30) Bezoules comes from the Greek for benches.

80 lbid., 25-27; Wookey, Fortuna, 21. (supra note 30)

81 Chariton lames Giraud (1869-1955), founder of C.J. Giraud and Co., Smyrna.

82 Willem Whittall (1915-1989) was the son of Charlton Frank Whittall, last of James' thirteen children, and his only child by his second wife, Anna Van Lennep.

83 Turrell, Scrap-book, 1809-1922, 212-14. 
The first wave of terror hit us in school one day when we saw the Turkish kids pull off their fezzes and rush back home as if pursued by the Devil. Distant explosions following, we were told that the Greeks had landed and vague rumours were circulated about the mistreatment (to put it mildly) of the local Turkish population. (There) followed two uneasy years of news of war and the revival of Turkish militancy under their vital new leader, Kemal Ataturk.

As a child one didn't realise much of what was happening except as the unspoken anxiety of our elders filtered through into our consciousness. So the climax and the harsh reality of war hit me suddenly as we were finishing the summer holidays at our Long Island home. ${ }^{84}$... The descent of relatives and friends upon our island solitude was spectacular. Boats kept rolling into the harbour and aunts and cousins arriving up at the house to take temporary refuge from an untenable situation in Smyrna.

It was eventually deemed safe to go back to the town although not safe enough to return to the country, so we all settled into isolated little pockets of the town. Mother and us children were parked in the house of an Armenian friend and I remember that Albert Alliotti, who was due to stay with us, left in a hurry because he maintained that Armenians were on a priority list for extermination and it wasn't safe to remain in an Armenian house. I wish I could say that I felt courageous at this point, but the truth is I was terrified. The sound of heavy gunfire was perpetual and I visualized graphically the retreat of the Greeks and the panic around me. The uncles would drop in of an evening to post Mother with all the scenes of horror that they had witnessed, with no concern for little ears that were taking it all in. I know that I used to go to bed and shake with fright until Mother joined me in the double bed. Somehow Mother chased away fear although I can imagine what her state of mind must have been like with Dad away and so much responsibility resting upon her.

The day we finally had to leave, for the town was on fire, Mother elected to have a big wash and all our clothes were strung out in the garden. At dusk Uncle Charlie called to say we must pack a few things and get out on to a boat that he had chartered to take family and friends to Greece. I remember crossing the quay in the dark with four-year old Margaret in tow and thousands of demented people running back and forth. At that point a goatcame charging down and butted Margaret, knocking her down, and she was picked up screaming to add to the turmoil and put on our launch, the Helen May, ${ }^{85}$ which was waiting to take us to the glorified tug on which all the family were parked. What a relief to get to the Helen May and steam away from the scenes of panic going on around.

A flaming town in the background, a port full of English warships, doing nothing except load up with refugees, and ourselves far enough away from it all not to have to witness more than an overall picture of the chaotic horror of war. Fortunately the night was calm and warm for we all lay in heaps on deck, our dogs nuzzling up on top of me shivering with nerves. ${ }^{86}$

Not all residents heeded the call of the authorities to leave. The Daily Mail reported that all British residents were evacuated "except a few individuals living in the suburbs who obstinately refused to go. One of these was Miss Woods, 65 , who lived at Bûrnabat." 87 Hortense Wood (1844-1924) was actually 78 years old. She was the oldest of seven children of Eugenie Maltass and Dr. Charles Wood, who had been James McCraith's partner in the practice at the British Maritime Hospital, Smyrna. Hortense Wood was a great feminist, as well as a poetess, composer and

84 The Girauds had a summer home on Long Island, a small island a few miles off the Turkish coast.

85 The family boat, the Helen May, was oceangoing but, with a small cabin and two berths, not large enough to accommodate all the family. Mary Whittall, A Book of Thoughts, 3 .

86 Ibid., 29-33.

87 In the issues for September 191922 cited by CFconomos, The Martyrdom of Smyrna, 73. (supra note 11) 
talented artist. She had studied the piano under Franz Liszt. She was an admirer of Kemal, writing him a number of letters of encouragement and congratulation over the previous three years. ${ }^{88}$ She lived in the family mansion with her married sister and brother-in-law, Louisa and Ernest Paterson, 89 and her widowed sister, Lucy de Cramer. ${ }^{90}$ A strong, if eccentric, character, Hortense felt she had nothing to fear from the Nationalist army in 1922 and looked forward to its coming. Her decision caused some consternation amongst the family members, most of whom were leaving at the suggestion of the British authorities. Hortense Wood was a faithful diarist ${ }^{91}$ and described the events leading up to the evacuation as follows:

Sept. 3, Sunday

Panic in town, Armenian and Greek families fleeing. Greek soldiers refused to fight. Up to now five men of war in port.

Sept. 4, Monday

Smyma is seized with panic, and so is Boumabat, and all its surrounding villages. People of every nationality are running away, even English. We, the Sykes, the Stevenses, Mary, Fred and Jane remain quietly here. 92 All sorts of rumours are afloat, some say 70,000 soldiers have thrown down their arms and refuse to fight. Thousands of deserters have taken to the mountains. People are a fraid of the retreating army pillaging and buming towns and houses, destroying everything they come across. They have more than once threatened to do this should they be forced to evacuate Smyrna. We'll see.There is great excitement, people are constantly arriving from town with the latest news.

\section{Sept. 5, Tuesday}

All sorts of rumours going about. Constantine committing suicide, Gounaris assassinated, etc., etc., all unconfirmed. Refugees continue pouring in. A hundred thousand have arrived in Smyma and are gradually sent off to the islands. The hospitals are full of wounded. The Herbert Whittalls, Charnauds, Charlakis, Reeses, etc., and many French families have left. Many warships expected, and allied troops.

$\ldots$

Sept. 6, Wednesday

Thousands of soldiers passed down the square, soldiers that have thrown down their arms and refuse to fight. With them were mingling hundreds of refugees, Greeks and Turks, men, women and children. A pitiable sight. Carts loaded with their belongings, mere rags, and broken chairs and boxes. Hundreds of camels and hundreds

88 Kalças, Gateways to the Past, 10-12

89 John Paterson, a Scottish corn merchant from Leith, came to Smyrna and made a fortune when chromium was discovered in the Fethiye district of Anatolia. He built a huge 38-room mansion on a 130-acre property in Bournabat. In 1922 the patriarch of the family was Douglas Paterson. In 1973 the house was turned into a carpet factory. Giraud, Family Records, 76 and Kalças, Gateways to the Past, 32-34, Ernest Paterson was Douglas's younger brother

90 Alphonse von Cramer came to Smyrna in the eighteenth century as Austrian Consul. His son Ambroise Hermann Cramer was raised to the nobility by Holy Roman Emperor Francis II in 1801. Ambroise's grandson, Norbert de Cramer, married Lucy Wood. Their children were Renée, wife of Alfred Lawson, Fernand, and Giselle, wife of American John Bowdwin.

91 Wood's last diary is in the possession of her grandniece Renée Steinbüchel of Bornova while the earlier diaries are with other relatives in London. Extracts from the diary covering August and September 1922 have been partially published in incomplete facsimile and Turkish translation in Türkmen Parlak, Isgalden Kurtulusa, vol.2 (Izmir: Duyal Matbaacilik, 1983), 445-535. Yjildiz Belger's comparison of the Turkish text with the facsimile pages indicated significant discrepancies. Therefore she tracked down the original text and permission was obtained to reproduce it. The extracts in this article are from Sally Gallia's transcription. Renée Steinbüchel request that any other use of this diary be with her permission only.

92 "Mary, Fred and Jane." Mary Whittall Giraud (1843-1932), her husband Frederick Giraud (1837-1922) and her sister Jane Whittall Wilkinson (1842-1928). 
of sheep. Where were they going? They themselves told us they did not know. There are sixteen men of war in the harbour and more are expected. - excepting ourselves and a few others all Boumabat has fled, fearing all sorts of dangers threatening them. I am sure nothing will happen.

Sept. 8, Friday

The admiral enjoins on all British subjects to take refuge in town if they want protection. So all our people left by the 7 o'clock train with the carriage that took them to the station loaded with valises. Lucy left reluctantly and very much worried with Fernand staying here and joining those who talk of getting arms and defending the place if attacked. She looked pale and had her pain. Louisa was excited and insisted on Emest going with her to town. They would have preferred remaining here-- Many rumours afloat - that Stergheathi declared to the consuls that he could no longer be responsible for the safety of the town, resigned his post and named a Turk as future Governor of Smyrna. Perfunctory booming of cannon. The army firing on the deserters on the hills.

Stergiathi's declaration led the Admiral and the Captains of the Allied warships to land marines and troops, and tomorrow, it is said, some of these will be sent to protect Boumabat.

Fernand was Hortense Wood's nephew, Fernand de Cramer, who also lived at the Wood house. After evacuating his mother on a British ship, he stayed with his Aunt Hortense throughout the period. He began a lengthy letter to his relations, soon after the Smyrna fire started, to inform them of the happenings in
Bournabat. This letter was not completed until several weeks had passed.

\section{DE CRAMER'S LETTER}

Originally in French the letter was translated into English according to a handwritten note at the top. ${ }^{93}$ The identity of the translator is unknown. The casual observer would conclude, from the unusual phraseology and strange tenses, that the translator was not fluently bilingual. The translation seems a literal rather than literary one, and appears to have been made using a small dictionary that may not have included idioms. The letter abounds with examples, sometimes humorous, where it is possible to reconstruct the original French with some accuracy. ${ }^{94}$ However, Mary Whittall stated that in her opinion the translation was in idiomatic Levantine English, spoken and written by most Bournabat residents who had not been sent to England to school. This seems quite possible since the French and English residents of Bournabat had been intermarrying for over a century with inevitable effects on both languages. Fernand de Cramer's translated account on the 1922 disaster reads as follows:

Letter from Femand de Cramer (Translation from French) ${ }^{9.5}$

How to begin! And How to end!!

Friday, September 8 th, as tidings became more and more alarming, Mother, the Patersons, Lawson and Mattheys left to spend the night in town; 96 in fact, all Boumabat had already been deserted by our world.

93 A copy of this translation was donated to McGill University Libraries by another of Edward Whittall's Smyrna-born granddaughters, Marjorie Miller Close (1911 - ). In 1910 Elsie Whittall married American tobacco executive, Gray Miller (1885-1947), who later served as President of Imperial Tobacco in Montreal (1925-1943) and of British American Tobacco in London (1943-1947).

94 For example, Je me precipite should be translated 'I rush over' not 'I precipitate myself'. In the transcription square brackets [ ] enclose words inserted for clarity that were not in the original text.

95 The parenthetical Translation from French is handwritten.

96 The individuals who left were Lucy Wood de Cramer (Mother), Ernest and Louisa Paterson (de Cramer's aunt), Alfred Lawson (husband of de Cramer's sister Renée) and Thetis (daughter of Renée Lawson) and her husband Tony Mattheys. 
I remained with Aunt Hortense, swearing to Mother who was already very anxious about me, to join her the next morning and give her my news.

The hundreds of thousands of refugees who were traversing Bournabat to go to the sea told us that their brothers, the Greeks, while retreating, were burning everything, obliging them to desert their own homes, and massacring the few Turks who remained, and it was invariably the same story repeated over a period of more than a week.

Friday night, far from suspecting that the Turks were only a few miles away, and to save Bournabat from the fate of all the other villages of the Interior, some gentlemen conceived the idea of organizing strong patrols of villagers to prevent the Greeks from annihilating us.

In consequence, in two hours' time strong patrols circulated through Boumabat from Havousa to Bozalan, 97 and all the Greek soldiers who passed by the club were disarmed.

After having given assistance to the refugees until half past five in the morning, I had gone quietly to bed. At a quarter to eight I was awakened by such a fusillade and such a horrible din that I was led to believe in a battle in the square itself. I inhabited the kiosque. ${ }^{98}$

I see from my window a crowd pouring out from the street and running with horrible cries towards SmyrnaWhat a spectacle! I cross the garden and see Aunt Hortense with all the servants and a few refugees, making signs to me to seek protection from the bullets that were raining in the garden. During a short lull I go out of the door to see by what means I can take Aunt Hortense to town,
When I perceived Charlie Wilkinson ${ }^{99}$ who was struggling to get in to the house of the H.W.'s ${ }^{100}$ so as to get back to his own house.

I precipitate myself. I catch him, insisting that he had a motor cycle, and I pray him to take my aunt.

"Of course", said he, "but it's broken. I will try to mend it." We went together and three quarters of an [hour] after, it was in working order, and the bullets were raining down thicker than ever. I traverse the two gardens to inform Aunt Hortense. Impossible to persuade her to make a decision. Another trip to Charlie's to tell him to go alone. Again I go to Aunt Hortense to try to decide her; again without success. ${ }^{101}$

To make a long story short, I said to myself that whether it was a bullet from a rifle here or a cannon ball at Smyma it mattered little, and that I had better go and quiet Mother, and fortunately, for I arrived in time to prevent her from being overcome.

I start then with Charlie, and near the Vrisaki ${ }^{102}$ [it was impossible to go further. The way is entirely blocked by the crowd and animals of all sorts. We decide to go back through the fields, pushing that heavy machine all the way. And the heat! When near the station [I] wait for trains which wait for no man.

I had just time to jump on the running board and the train had not made one hundred meters, when a terible machine gun fire descends on Boumabat!! I spare you the description of the people on the train! Greek soldiers preventing poor maddened women from getting aboard! etc., etc.

97 Havousa was the pond at the top of the village. Bozalan (Boz Alan or Champs des Emigrés) was the open countryside at the bottom that was used for newer housing construction.

98 De Cramer, in the warm season, was sleeping in the kiosk, or summerhouse, in the Wood garden.

99 Charles Wilkinson (born c. 1878) was the British Consul-General in Smyrna. He was the grandson of James Whittall of the Big House by his third child, Jane. McKernan, p. 33. All the Wilkinsons seemed to be in consular service. His father, Richard, had been Consul General at Manila and his son, Richard Edward, was also Consul Ceneral at Izmir.

100 Wilkinson's uncle, Herbert Octavius Whittall, built the Wilkinson house on his own property for his niece Jane when she married Richard Wilkinson. Kalças, Gateways to the Past, 30. Wilkinson had to get into Whittall's house to get to his own.

101 In her diary entry for Saturday September 9, Hortense Wood describes these events as follows: "A good deal of firing in the street all the morning. I induced Fernand to accept a seat in the Wilkinson's car to return to town to allay Lucy's anxiety. She felt and looked ill. I felt much relieved when he left. After trying but in vain to persuade me to go too. The shots all round now fell thick and fast. Many people killed, they say. I don't quite believe it." Wood might have been more shocked had she realized de Cramer wanted her to go on a motorcycle, and that he himself had to take the train under harrowing circumstances.

102 The water tap by the road to Smyrna - the consumer end of Edward Whittall's public water supply system. 
At Smyrna at every yard people stopped you by force to obtain news. The Turkish cavalry was passing over the quays forty minutes after my arrival at home!!! Stupefaction, astonishment, amazement of everybody who thought them at least at two days distance!!!

I do not believe that any army in all history has ever covered more than 500 kilometres in less than fifteen days, five of which were spent in fighting entirely in one place.

You must realize that neither the infantry nor the cavalry found trains at their disposal and that they had to walk over roads, mountain passes, trails which covered more ground than the railway. It was astonishing to see these men - their form on horseback as well as their equipment!

Unfortunately between the passing at a gallop of the cavalry and then the infantry and then the bands of terrible irregulars, our beautiful Bournabat has forever been destroved for us.

Later - the troops which followed in a few days penetrated into the houses already gutted, and took what was left, and, alas! for six weeks after it still continued secretly.
Not the inhabited houses, of course, and let it be said there were no forced attacks for a long time. The only houses in all Bournabat that remained intact are the Paterson's, Harry and Jim Giraud, ${ }^{103}$ Eric. Wh., ${ }^{104} \mathrm{H}$. Joly ${ }^{105}$ and R. de Cramer (Bebo), ${ }^{106}$ as well as that of the Lawsons, where I have installed an Albanian. You would not believe your eyes if you saw the houses of Sydney Lafontaine, ${ }^{107}$ Keyser, ${ }^{108}$ Richard Whittall, ${ }^{109}$ Molinari, Frank Wilkinson, Ed. Lafontaine, ${ }^{110}$ H.W. Pagy, ${ }^{111}$ Charlaki, W. Charnaud (only partially destroyed, fortunately), Mattheys (completely, alas!), Sunoman, Fritz, ${ }^{112}$ Mme. Turrell-Murphy (they killed M. and wounded his wife), ${ }^{113}$ Reggio, ${ }^{114}$ in short, all the houses so far as the station, and in most of them, without taking into account the total pillaging, a vandalism without name. All the Greek houses large and small as far as the Havousa are but a ruin without name.

In the pretty Protestant cemeteries all the monuments and crosses are in rags, broken in fits of rage (the dirty Cretans ${ }^{115}$ of this place are largely to blame!) and as far as the Catholic and Greek cemeteries, many of the vaults

103 James Richard Giraud (1882-1968), youngest brother of Edmund Giraud, worked for Charlton "Charlie" Giraud.

104 Eric Whittall.

105 Herbert Joly worked in Edmund Giraud's cotton factory. Source: Whittall, A Book of Thoughts. (supra note 30)

106 Richard "Bepo" de Cramer, father of I.R. Wookey's best friend Richard "Dicko" de Cramer, apparently lived on family wealth inherited from the de Cramer banking business. Source: I.R. Wookey.

107 Sydney James La Fontaine (b. 1846) was married to Edith Amelia Whittall, twelfth child of James Whittall.

108 The Keysers were originally a Dutch family of merchant bankers who had gone to England with William of Orange. William did not repay the money loaned him resulting in a prolonged Jaw suit against the crown. The bank is now called Keyser Ullman. In the nineteenth century a Keyser came out to start a Turkish branch, called the Bank of Salonica which was later absorbed by the Ottoman bank. Wookey, Fortuna, 6.

109 Richard Watson Whittall had died in 1920, one year after his son Richard James Whittall. Their house might still have been called by that name, or it may have been the house of Leonard Richard Whittall (b. 1893), son of Charlton Francis Whittall (18641942).

110 Probably Edward Leonard La Fontaine (b. 1890), son of Sydney La Fontaine, supra note 107.

111 Sieur Gabriel Pagy came from Marseilles to Smyrna in the early eighteenth century. His company was involved in cotton handling.

112 Frederick "Fritz" de Cramer was married to Mary, daughter of Richard Watson Whittall. McKernan, The Ceneology of the Whittall Family of Turkey, 43. (supra note 30)

113 Details of this incident are given below.

114 The Reggio (or Raggio) family came from Cenoa to Chios in 1360 , moving on to Smyrna before the Chios massacre of 1822 during the Greek War of Independence. Kalças, Gateways to the Past, 38; Turrell, Scrap-book, 1809-1922, 151.

115 "Cretans" or Turco-Cretans were Greek-speaking Turks who had been forced out of Crete as the Ottoman Empire contracted. They, along with Greeks and Armenians, had formed the domestic servant class in Bournabat. Source: Mary Whittall. 
and coffins have been rifled and a mass of dead, known to us all, lamentably exposed. The Protestant church has had all its stained glass windows broken, all the upholstered benches torn apart, and horses were stalled for several days in the altar enclosure.

Finished, finished is Bournabat for us... In less than three weeks they have expelled all the Greek inhabitants of the city and all the refugees of the interior. Can you picture to yourself this country without one Greek. In no country have I ever felt like such a stranger as in our old Bournabat. Not speaking a word of Turkish!

The houses of Charlie and Ed Giraud in Smyrna ${ }^{116}$ have been saved in time for the occupation of the Pashas. The damage is slight. It is, after all, Bournabat that has had the greatest number killed. The minimum is $1,200 !^{117}$ As for the Armenians, very few have been able to leave town. I will admit they did all they could to bring it upon themselves, and they succeeded too well, and, alas! how many innocents! I was able to return to Boumabat two days after the occupation to see Aunt Hortense. I saw four arabas ${ }^{118}$ over-full of dead, which they were transporting in the direction of D. Paterson's.

Let us come back to town, Wednesday, the 13th, at two, Patersons and Lawsons were leaving with the English, and I stayed alone with Mother, the cook and two servants at the Smyma house. There was a fire in the direction of Basmahane 119 but no one paid any attention to it.

At about five or six o'clock that day first signs of anxiety. The wind is blowing toward the sea. At ten it became serious and the wind persisted. At eleven I decided that Mother should go to Stepho Psiachi ${ }^{120}$ who seemed to be out of the line of smoke. I spare you my anxieties in regard to Mother! I went back toward the house saying to myself that perhaps, seeing from the ships that the house would surely burn, they would send for her from the consulate which was in communication with the men-of-war. Vain expectation! Seeing that not only our house was going to take fire, but that of Stepho would burn also and that Mother would not survive in a crowd so horrible, atrocious, compact and panic stricken, [wel flew toward the quay resolved to [try J anything. At last I was able to make myself heard by a superior officer. I told him that she was a born English woman and that her life was entirely in his hands. Thank God I was able to take her through the crowds, but at what a cost! And I left her in the boat three-quarters unconscious. Ah, my dears! Never will I be able to describe what I suffered at that moment. I am sure she has already given you all the details in their breadth and length. It was just one month after that that I had news of her and she of me. I went back to the house to find the servants, whom I lost about two in the moming near the pier, a prey to the most atrocious fear that I have ever witnessed. Picture to yourself a crowd so dense that you could scarcely touch the ground with your feet and you turned upon yourself like a grain of sand in a whirlwind. Amid piercing shrieks, blows, people were falling into the sea, a smoke, so hot that upon my word I thought my entrails were on fire. It was under these conditions that towards six o'clock I found myself dragged towards the point. ${ }^{121}$

A second day more terrible still, also what a night! It is not until late the third day that I was able to find myself again at Bournabat near Aunt Hortense and the house occupied by Fevi Pasha, Marshall in Chief to the Armies

116 Edmund Giraud did not own a house in Smyrna. "Ed" therefore must have been his brother Edgar (1871-1950)

117 The only British nationals reported killed at Bournabat were Dr. Murphy, see infra, and Lydia Maltass, a Bible reader. The vast majority of deaths were reported to be the Greek and Armenian servants of the European houses. CEconomos, The Martyrdom of Smyrna, 138, 143. (supra note 11) De Cramer obviously had no idea of the scope of the disaster in Smyrna.

118 Large wagons or carts, although in Ottoman Turkish the word can mean any wheeled conveyance drawn by animals including carriages for the nobility.

119 The railway station.

120 The Psyachi (or Psiachi) family, Greek merchants, had had a house in Bournabat. Kaiças, supra note 30 , p. 17. The Psyachi appear to have come to Smyrna after the destruction of Chios in 1822

121 The Point or Daragaz Point at the northern end of the quays 
of Kemal Pasha. The latter ${ }^{122}$ came to our house three times, complimenting Aunt Hortense and kissing her hands. He is a real charmer! We know all the great personages of the great national assembly.

Several officers told me afterwards how much they disliked the deeds committed at Boumabat but that unfortunately all the troops during fifteen days had seen nothing but burned villages and all their people had been massacred and burned without exception.

Helas! It was confirmed by international journalists with proofs and corroboration. It was a miracle that they did not kill us all. The fire at Smyrna was undoubtedly started by the Greeks and Armenians. Besides, the Greeks had been saying for five months that [when] they were compelled to leave nothing would be left standing. May the devil take them forever, as well as Lloyd George. And yet without servants and other conveniences we will never be able to stay.

I will give other details soon.

Letters, cheques and telegrams arrived.

Fernand.

The letter raises a number of questions that require context. The vilification of Lloyd George is relatively straightforward. The British and French offered Greece Anatolia as a sphere of influence if they would join the war against the Central Powers in 1915.123 Eleutherios Venizelos, the Greek Prime Minister, was most anxious to declare war but King Constantine insisted on a policy of neutrality. Venizelos resigned and established a revolutionary government in his native Crete, declaring war on the Central Powers in November 1915. Since Greece refused to enter the war, the west coast of Turkey was then offered to Italy as an inducement to enter the war against Turkey.
Greece later entered the war in 1917 when King Constantine abdicated and Venizelos returned to power. When the war ended the Allies found them in the unfortunate position of having offered western Anatolia, including Smyrna, to both Italy and Greece. In trying to settle this matter Lloyd George was perceived to have a bias in favour of Greece and his views ultimately prevailed when the Supreme Allied Council authorized the Greek occupation. To most Turks, who might have accepted British rule, this event was an intolerable provocation and became "a clarion call to Turkish nationalism". ${ }^{124}$

In pursuing his policy Lloyd George ignored all the advice proffered by the Foreign Office and the Foreign Secretary and, as early as 1920, the UnderSecretary Lord Hardinge wrote to a colleague:

Nothing could have been more mismanaged and we are only at the beginning of our trouble with Turkey over the conditions of peace. All those with experience and knowledge of Turkey and of Near Eastern policies have been ignored and the views of cranks and enthusiasts adopted. The merest tyro who has lived in Turkey would know that the Turks would never agree to give up Smyrna and Adrianople to the Greeks whom they both hate and despise. ${ }^{125}$

Over the next three years Lloyd George continued to support Greece even after the other allies became increasingly nervous about the offensive against Ankara. There can be no doubt that Lloyd George's policies, which ultimately resulted in the destruction of Smyrna and his own fall from power, gained him the bitter enmity of Turkey and, almost certainly, that of the European residents of the affected area.

122 The phraseology is confusing here. In fact "the latter" was Kemal himself who visited the house three times and complimented Hortense Wood. Fevzi Pasha was living in the Wood House with Hortense Wood and de Cramer.

123 Housepian, The Smyrna Affair, 37.

124 ibid., 52-53.

125 Quoted in Ephraim Maisel, The Foreign Office and Foreign Policy, 1919-1926 (Brighton: Sussex Academic Press, 1994 ): 66. 
De Cramer mentions that Mme. Turrell-Murphy was wounded and her husband killed. Colonel Murphy, 81, was a retired army surgeon from the Anglo-Indian Medical Service living on pension at Bournabat. There are various versions of how he met his end. The general consensus is that Turkish soldiers or irregulars entered his house for loot and with the intention of violating the servant girls. A great deal of damage was done and Murphy's family was attacked. Murphy himself had large china vases thrown at him and possibly received other wounds when he tried to protect his servants, his family and his property. Sir Harry Lamb, borrowing two cars from the American consul, evacuated the family but Murphy died that night. ${ }^{126}$ Other accounts reported more graphic, unverifiable and improbable detail:

Among the refugees is the wife of Dr. Murphy. He had formerly been in the Indian service, and for many years had been settled in Smyrna, where he was known for his philanthropy. It is said he met his death at the hands of a Russian Jew, a soldier in the Turkish Army. This man, after receiving from the doctor all the coin there was in the house and a cheque for $£ 2000$, struck him down with his sword, and hurled pieces of valuable crockery at him. The soldier then commanded Mrs. Murphy to play the piano. She fled, pursued by the soldier, but was succored by an Allied patrol. The doctor was taken to hospital where he died. ${ }^{127}$

Turkish sources indicate Murphy's death was as a result of a misunderstanding with military police, trying to enter his house to catch a looter they were following. During the confrontation between the military police and Murphy, one of Murphy's servants shot at the intruders. Shots were exchanged and Murphy was killed in the crossfire. ${ }^{128}$

Hortense Wood reported the incident somewhat more plausibly than some of these other accounts as follows:

A young Italian employé at the Italian consulate brought me letters from town. He was extremely nice and slapped a Bashibouzouk ${ }^{129}$ in the face before me-an awful looking man. I wondered he was not afraid.

Dr Murphy was fired at by Bashibouzouks and is dying, Mrs Murphy was horribly ill treated, beaten and her face covered with wounds. The girls were also ill-treated. Everything has been stolen from them-their money, their silver, all they possessed. They have taken refuge at the Lawson's house. Wrote all about it to Ernest begging of him to apprize the B. Consul. ${ }^{130}$

The following day she wrote: "I had the opportunity of sending my letter. It produced the desired effect. - Ernest spoke to Sir H Lamb who came out to see Dr Murphy, and on returning to town saw the Vali \& informed him of what was going on here."

De Cramer's letter is ostensibly pro-Turkish, rationalizing the excesses of Kemal's forces in exculpatory fashion while blaming the Christian minorities for a variety of ills in almost standard propaganda phrases. Yet these attitudes are seemingly inconsistent with other evidence about de Cramer's beliefs and require closer analysis. Other than family concerns, de Cramer's greatest lament is for the destruction of his beautiful Bournabat which was to lose its name, like Smyrna, and become Bornova. It is clear that the absolute responsibility for this destruction lay with the Turkish military. The local

\footnotetext{
126 Horton, The Blight of Asia, 134-35, (supra note 11); Smith, Ionian Visions, 307, 307; Daily Telegraph (September 20, 1922) in (Economos, The Martyrdom of Smyrna, 80. (supra note 11)

127 Times (London) (September 20, 1922), reproduced in CEconomos, The Martyrdom of Smyrna, 143.

128 Parlak, Isgalden Kurtulusa, vol.2, 453. (supra note 91)

129 Başbozuk are literally 'spoilt/broken heads' generally meant bandits or hooligans. Here it refers to irregular troops. See note 25.

130 September 11, 1922.
} 
vigilante militia had succeeded in disarming the retreating Greeks, preventing them from doing any damage. De Cramer was also sympathetic to the refugees, presumably mostly Christian Anatolians who retreated with the Greek army, staying up until 5.30 AM to give assistance - unusual for someone to whom life without "servants and other conveniences" would be insupportable. It was the cavalry, the infantry and the bands of "terrible irregulars" who looted and destroyed the houses. While excesses might be expected in the first few days, problems continued even when Kemal's staff was headquartered in Bournabat. Every insult seems to have been offered to Christian institutions and symbols from the breaking of crosses and stained glass windows, to the rifling of graves. The villas of Bournabat would have had sufficient actual stables for the horses of the Turkish military, so it would not seem to have been a military necessity to desecrate the altar enclosure of Charlton Whittall's church. It was the Turkish residents of Bournabat, albeit Greek-speaking ones, who had allegedly fragmented the monuments in the Protestant cemeteries, although the motive for this action is unclear.

Despite the destruction of the victors and persecution of the innocent, de Cramer seems to accept the Turkish justifications for the actions of the military. Though appalled at the slaughter of innocent Armenians, he seems to believe that they brought it upon themselves presumably through the actions of a few resistance fighters and three years of cooperating with the Greek administration. Although it is certainly true that some Armenians welcomed the Greek takeover and a few resisted the Turkish armed forces, ${ }^{131}$ this could never justify the subsequent reprisals against civilians. De Cramer also accepts the fact that the Greeks and Armenians started the fire, although the source for this information is most likely to be the many Turkish staff officers with whom he came in daily contact. Indeed, given the fact that the Greek and Armenian populations had been killed or evacuated by the time the letter was written, de Cramer's sources could only have been Turkish. At other times, however, de Cramer simply reports what Turkish officers have said without making any judgement regarding the validity of these statements.

There are basically two possible explanations for these contradictory elements in the letter. Most obviously, de Cramer, doubtless influenced by his inimitable Aunt's opinions and his daily interaction and friendship with the Turkish officers, could simply have believed what he was told about responsibility for the catastrophe. It should be remembered that the Bournabat Europeans had always been proTurkish and had viewed the Greek takeover with grave misgivings. ${ }^{132}$ Also, his belief could have been strengthened since he was grateful for the "miracle that they did not kill us all". ${ }^{133}$ A more subtle explanation would be that de Cramer felt that he and the other Europeans still had a long-term future in Smyrna. He must have known his letter might receive broader circulation. He knew also there was a possibility that it might be intercepted. In short, he knew that Turkish authorities might read his words at some future time. A prudent man, therefore, might be careful just how he described events and how he assigned blame. It could well be important to appear to accept the Turkish position. It is difficult, of course, to attempt interpretations of de Cramer's motivation when using a translation since subtle shades of meaning are hard to differentiate. It seems likely that de Cramer wanted to convey a great deal of personal information about friends and their property, while

131 Kinross, Atatürk, 370.

132 Housepian, The Smyrna Affair, 69.

133 This type of identification with the perpetrator that appears to fly in the face of logic can be found in such things as the Stockholm syndrome. While not a kidnap victim, de Cramer was clearly a hostage to fortune. 
avoiding potential alienation of the future powers to be. If so, he probably succeeded.

If de Cramer's reason for writing as he did was prudence, then his reaction does not appear unique. Fsther Lovejoy, who was president of the Medical Women's International Association (1919-1924), was on the quays of Smytna in the last week of September, one of three western doctors trying to help the refugees. She was upset by the way the Turkish military treated the refugees and was surprised that a fellow American, a businessman resident in Smyrna, always seemed to find excuses for the Turkish behaviour. Finally, with Lovejoy threatening to publicize these events on her return to the United States, the businessman said plainly: "Dr. Lovejoy, please be careful what you say about all this in the United States. Remember, we have to live here." ${ }^{134}$

\section{KEMAL'S BOURNABAT HEADQUARTERS}

De Cramer's claim to know all the great people in the nationalist movement was not exaggerated. Bournabat was used as both the military and political headquarters for the Kemalist forces after the liberation of Smyrna, and most prominent members of the movement visited there in September. Many biographies of Kemal tell a charming and romantic story from this time. The day after Kemal entered Smyrna, a young woman came to see him. Latifé Hanum, the twenty year-old daughter of Smyrniot merchant Ushakizade Muammer, was a welleducated nationalist who carried Kemal's picture in a locket. She told him that her parents were in Biarritz and offered their house to the man she admired so much as his headquarters while in Smyrna. Kemal, finding both her and her offer irresistibly attractive, immediately ordered the transfer of his headquarters to Ushakizade's villa in Bournabat. ${ }^{135}$ One source $^{136}$ goes so far as to explain that Göztepe is the Turkish name for Bornova. The story continues that Kemal's staff had to find quarters in Bournabat for themselves and their horses. Kemal's desire to consummate an affair with Latifé was not satisfied by the time he left Bournabat for Ankara at the end of September. She told him frankly she would be his wife but never his mistress. Six weeks later Kemal returned to Bournabat and married Latifé in her father's house. ${ }^{137}$ Charming and romantic though this story is, it is unfortunately not quite accurate. Kemal did meet Latifé at this juncture, did move his headquarters to the house of a female admirer, did spend some time at the Ushakizade villa in Göztepe, and did return to marry Latifé. However, Göztepe is nowhere near Bournabat.

Kemal prudently transferred his headquarters to Bournabat after the Smyrna fire started, and all his senior staff officers took up residence there. The actual headquarters were placed not in Latifé's father's house, but in that of an older admirer, Hortense Wood. Fevzi Pasha, the Chief of Staff, seems to be the only senior officer who actually resided in the Wood home, while Kemal's other key advisor Ismet Pasha occupied the nearby house of Mary Whittall Giraud, sister of Edward Whittall and mother of Edmund Giraud. Kemal held his staff meetings, planning the last phase of his campaign of liberation, in the Wood house, and allowed Hortense Wood to act as his hostess. In her diary she described the coming of the pashas as follows:

Sept. 9, Saturday

\footnotetext{
134 Esther Lovejoy, Certain Samaritans (N.Y.: Macmillan, 1933), 161.

135 Kinross, Atatürk 372-375. See also Dagobert von Mikusch, Mustafo Kemal; Between Europe and Asia (N.Y.: Doubleday, 1931): 330-34; H. C. Armstrong, Grey Wolf: Mustafa Kemal, an Intimate Study of a Dictator (London: Barker, 1932): 199-204, and Brock, Ghost on Horseback, 277-86.

136 Kinross, Ataturk, 373.

137 Ibid., 418-19; von Mikusch, Mustafa Kemal, 330-34.
} 
A good deal of firing in the street all the morning... I was glad to witness the entry of the Kemalist cavalry from the Kanghelakias ${ }^{138}$ of the kiosk. Splendid men wearing new, spotless uniforms and circassian caps. Perfect discipline and perfect quiet. The horses were in a very good condition. I wonder what impression they made as they entered Smyma and rode along the quay. They must have enlisted everybody's admiration and surprise. Not a shot was fired. And thus came the change from Greek to Turkish administration, in perfect tranquility and against all expectations and apprehensions. The Turkish gendarmerie was quickly formed in Bournabat and two gendarmes were sent to each European house to protect it from Greek looting and fire. - Before entering the village the Turks had warned the population that the Kemalist army was coming and that it was advisable every body should keep indoors. The advice was disregarded and Greeks fired on the Kemalist soldiers. These retaliated, hence all the shooting that scared people all the moming. This evening all is quiet.

Sept. 10, Sunday

I was called downstairs to meet the chief of the police, the Co .... ${ }^{139}$ of the Kemalist army, a colos ... the Mufdi of the village, haim... belonging to the police staff. They asked me whether I could lodge Noureddin Pasha and his adjutant. I said I was sorry we were very numerous in the house and could only spare one room. They said they would see whether they could find another house with more rooms before deciding to take our room. They were very friendly and nice. The chief of the police taking notes all the while. They were accompanied by the Armenian doctor, our neighbour, who was their interpreter. Before them other Turks came, a Bey, another gentleman whose name I don't know, Mr. Baladour, and someone else, a silent member of the party. In the afternoon I was agreeably surprised to see Fernand and Mr Mattheys they came in a car to take some things kissed me and went off. All our people in town are well.

Moustapha Kemal is in Smyrna!!

Incognito for the present, disguised as a cavalry officer. I am sure he was one of the men of the cavalry that quietly rode along the quay under the very noses of the Allied fleet that fill the harbour, and that the 200 Cavalry men are his bodyguard! What a tum played to the Powers! As the cavalry passed along the quay the British marines presented arms, not knowing whom they were saluting!What will Lloyd George say now? Kemal is greater than he. - About 1000 people are reported to have been killed during the firing this morning in Boumabat.

I was dreadfully distressed [to hear] that Edith's house left ulnattended] and with both doors wide open [was] sacked! How will she bear this misfortune! Dr Denotowitz ${ }^{140}$ gave me this news. He came here and was quickly called away and told to go home and keep indoors. The situation was dangerous. P. Pagy's ${ }^{141}$ house was also looted and other houses too I am told. - Reggio's, Edith Lawson's, etc.

\section{Later}

We were terrified last night when a great fire broke out quite close to us. Manoclo's house was burnt down. Tremendous clouds of smoke, in the midst of which flames lept sky high and millions of sparks flew over our tiles and fell into the garden. At one time it seemed as if the stables had caught fire. The horses had been stolen that very morning by Bashibouzouks. By midnight the fire had been smothered by soldiers knocking down walls.

\section{Sept. 13, Wednesday}

Our people went on board an English ship ... Later on Fernand took his mother on the quay, spoke to an Englishman guarding a boat, told him his mother was

\footnotetext{
138 Iron railings.

139 ".." indicates corner of pages missing, affecting several letters.

140 Christian Denotovich (1880-1943) was the village general practitioner.

141 Pierre Pagy.
} 
English but married to an Austrian. The officer took Lucy in his boat. She was taken on board a ship, \& was probably transferred to the boat where the Patersons and Lawsons were. - We have had no news of them sinceneither of Maria, Aphrodhiti and Atheio. ${ }^{142}$ Fernand last saw them in the crowd running to save themselves from the fast coming on of the fire.-Smyma was then blazing.

Sept. 14, Thursday

Arrival of Fevzi Pasha and his staff. Asks for rooms for himself and eight officers. - I said I expected the return of my people in a day or two, \& could not give up my sisters' rooms. I could only place two rooms at his disposal. He sent for the Mudir ${ }^{143} \&$ told him to find accommodation for his staff in some other house. He did not wish to annoy me he said. - I had to give up Emest's room, \& the two rooms I had already offered him.

Sept. 15, Friday

Richard Abbott comes with a message from the B[ritish] vice consul waiting outside with a motor car \& offering me a seat to take me to town, 'my last chance' he said. I thank \& decline, preferring to remain quietly here!

The town set on fire. We can see the red glow illuminating the sky \& glowing smoke ascending ever higher. Bombs are constantly exploding \& the sound reaches $u$ s very distinctly. I am anxious about my people, although I am sure they are safe on board. - No communications whatever with the town. No trains, only military autos.-

\section{Later}

Distracted refugees escaping from town, now almost totally destroyed. All the beautiful houses on the quay gone. The Paterson's piéd à terre, the British, French and American consulates all in ruins.

Sept. 16, Saturday

Arrival of Kemal Pasha in our house, together with lsmet
Pasha and other generals, \& the famous Turkish lady, Halide Edib Hanoum. I received them and expressed my joy at making the acquaintance of Kemal, I so admire. After a quarter of an hour's conversation with me, Kemal with five others went upstairs to discuss the answer to the Allies. The fate of the Empire was being discussed just outside my bedroom door, near the piano. These gentlemen dined here \& later on Kemal asked for a bath. He had one, after which we renewed our conversation. He promised to come again.

Halide Edib (1885-1964) was a teacher, novelist and, at this time, Kemal's chief propagandist. Considered Turkey's first liberated woman, she left her first husband in 1910 when he took a second wife. She married again in 1917, to a Turkish politician, Adnan Adivar, and was exiled (1925-1938) when her husband was accused of plotting against Kemal. She returned to Turkey in 1939 after both her husband and Kemal had died, teaching at Istanbul University and serving as a Member of Parliament (1950-1954).

Sept. 17, Sunday

Trains begin to run. Villagers are allowed free circulation, but are still timid and frightened. Most of their belongings have been stolen and their houses wrecked.When Kemal's cavalry entered Smyma the Greeks shouted: Zito o Kemals! Zito o Kemals! $!^{144}$ \& an image of the Virgin was kissed \& handed from one to the other all down the crowd along the quay!

Kemal, Fevzi, Ismet, Azim Pashas assemble in Emest's room \& discuss the political situation, and leave to visit Nourredin and Emin staying at Ed. Whit. Ismet is staying at Mary G's.! Every house is occupied by officers and their men.

September 18, Monday

No news from anywhere, no letters no papers.
142 Greek maids.

143 Müdür, is Turkish for manager, supervisor or overseer.

144 Long Live Kemal! (Greek) 
Ismet Pasha, Fevzi Pasha and Azim Pasha dine here. \& after dinner Ismet and Fernand play several games of chess, Ismet wins one, and Fernand two. - I go to bed at 11. Fevzi retires some time after, but Ismet and Fernand sit up talking until 1 in the morning. A heap of papers are brought to Fevzi Pasha who is Minister of War for him to sign. Azim Pasha and I talk in German. His pronunciation is defective.

Ismet's son, Erdal Inönü, recalled his father's legendary passion for chess as follows:

One of my father's most favored past times was to play chess. In his memoirs he says my grandfather loved to play chess and he himself learned to play it at an early age. In his library at home he had lots of chess books. He was also a subscriber to a monthly chess magazine from Germany. He always read them, and he used to say 'I must have read a thousand pages on chess'. He liked to play chess with his close friends... When we had important guests at night, and after the guests had gone, my father had the habit of playing chess by himself for an hour or so before he went to bed. He enjoyed playing chess but he took it seriously - he always played to win. When he won, he was pleased, when he lost (which was rare) he would sulk or say something like 'Oh, you were so lucky' and in that case he would usually insist on another round-until he won. ${ }^{145}$

Wood continued her daily account:

September 19, Tuesday

A French Admiral has come to see Kemal. Fevzi went to town to meet them. Sari ${ }^{146}$ Pasha has arrived from London. - Fernand with a Turkish friend, an old acquaintance, took a turn in the village and was impressed and saddened by all he saw. The gates of houses left wide open, the houses looted \& deserted, the streets empty. The village abandoned by all former residents \& our friends. - Will they ever return! -

Sept. 21, Thurs.

Azim Pasha came to fetch Fevzi $P$. to go to town where they were to meet all the Angora Government Officials just arrived from Angora. - General Pelle is here. - The French, Italian \& American Consulates are said to have begun work. Azim told me that Halide Edib Hanoum intended to come and see me probably tomorrow.

General Maurice Pellé (1863-1924) had been the French High Commissioner on the Allied Supreme Council, Constantinople since 1920. He left Constantinople on a warship for Smyrna without informing his Allied colleagues. He hoped to extricate France from its commitment to support the Allies at Chanak by persuading Kemal to respect the Neutral Zone. Kemal rejected this proposal averring that he did not recognize the Neutral Zone. ${ }^{147}$

\section{September 22, Friday}

The Angora Govt. arrived in Smyrna this morning. Ismet Pasha brought them out to the country. Raouf Bey "President du Conseille" Fuad Pasha and others were introduced to me. Then they went upstairs joined Fevzi Pasha and discussed affairs in the hall upstairs.... Fevzi and Ismet fr. town late. I had their dinner brought to them here. I feel tired. Left Fernand and Ismet playing chess.

Hussein Rauf, an Ottoman naval hero, who, as Minister of Marine, had negotiated the Armistice of Mudros, was Prime Minister in the Grand National Assembly at this time. After breaking with Kemal and Ismet in 1923, he led the opposition until he was tried for treason in 1926 and exiled. Ali Fuat was an

145 Erdal Inönü, Anilar ve Düsünceler, vol.1 (Istanbul: Idea lletisim Hizmetleri AS, 1996), 51-52. Summary translation provided by Yildiz Belger.

146 Writing not clear, although Fethy Bey, see infra, had just returned from London

147 Kinross, Atatürk, 378-79 
Ottoman general who joined Kemal's nationalist movement after the war. He served as Ambassador to the Soviet Union after he was replaced by Ismet as commander on the western front. At this time he was the president of Kemal's Defense of Rights party in the Grand National Assembly. He also joined the opposition to Kemal and was tried for treason at the same time. Unlike Rauf, he was acquitted.

Sept. 23, Saturday

In the afternoon Fevzi and Ismet $P$. came from town with Fethy Bey who looks a dull Turk, but is not probably so. He has just returned from London where Lloyd G refused to see him. Curzon too.

Ali Fethi, a schoolmate of Kemal's, was Minister of the Interior in the Angora government. He had been sent as a peace emissary to Europe to discuss a Greek evacuation in case the Smyrna campaign did not go well. He later succeeded Rauf as Prime Minister.

At this point in time the Allies, collectively and separately, were trying to find diplomatic solutions to end the hostilities. Kemal's forces were advancing on the Dardanelles at Chanak, where British, French and Italian forces guarded the Neutral Zone established by the Treaty of Sèvres. France especially was intent on an agreement since her own treaty with Kemal, negotiated by Henry Franklin-Boullion (18701937), was still secret. Wood's diary gives an interesting backdrop to the Turkish side of the affair. Within a week, however, she noted sadly that her Pashas were all leaving as the locus of the drama shifted north. Smyrna was left to its governor, Nureddin Pasha.

\section{THE AFTERMATH}

For many days some $300,000^{148}$ refugees, caught between the fire and the sea, remained on the quays of Smyrna awaiting word of their fate. On September 16 the Turkish authorities announced that all male Christian refugees between the ages of 18 and 45 were prisoners of war and would be deported to the interior, considered the equivalent of a death sentence. Of this Horton wrote:

One of the most outrageous features of the Smyrna horror was the carrying away of the men between the ages of eighteen and forty-five. These were inoffensive farmers and others, in no wise responsible for the landing of the Hellenic arny in Asia Minor. They were the bread winners and their forcible detention left widows and orphans to be supported by the so-called "Christian nations," especially the United States. ${ }^{149}$

The Turkish authorities also stated that the remaining refugees could be evacuated but, if they were still in Smyrna on October 1 , they too would be deported. This Turkish order referred not just to the refugees, but to all Greeks and Armenians in the area as Hortense Wood make clear in her diary:

\section{Sept. 26, Tuesday}

Poor Calliopi came to my room sobbing. She went to her house and found it pillaged. Every stick and rag in it stolen. - It is rumoured that all women are to leave the country. It would be a disaster for them and for us. - What are we to do without servants!... They are pessimistic. Our pashas looked glum today. Things are not going well probably.

148 Prior to the disaster the population of Smyrna had only been some 300,000 of whom at least half were Greek. Source: Encyclopcedia Britannica 11 th ed. (Cambridge: University Press, 1911), 25:284. This number had been significantly swollen by the tide of refugees from the interior. Another population estimate states that before 1922 Smyrna had a cosmopolitan population of 270,000 inhabitants composed of 140,000 Greeks, 80,000 Turks, 12,000 Arrnenians, 20,000 lews and 15,000 Europeans including Levantines. The latter were descendants of British, Dutch, and French who had settled some 100 years earlier in the Near East. <http://www.jetcity.com/-azdarar/smyrna.htm>

149 Horton, The Blight of Asia, 165. 
Sept. 29, Friday

Our pasha has been spending all day in town with all the other Pashas discussing the situation with Franklin Bouillon.

The discussions with Franklin-Boullion led to the Conference of Mudanya, which opened on October 3 and ended the hostilities. Meanwhile huge efforts were made to meet the Turkish evacuation timetable and success came with six hours to spare. Greek ships, flying no flag, were allowed in the harbour and, with the help of the American and British navies, 180,000 evacuees were taken off. Most were initially transported to Mytilene (Mitilini) on Lesbos, although families were broken up in the chaos and panic, and some ships went to other ports. Turkey was prevailed upon to give a further eight days grace allowing the British and Greek fleets to evacuate another 60,000 refugees from the nearby ports of Urla, Chesme and Ayvalik. The question of the deportees, or prisoners of war, was not considered until the Treaty of Lausanne in 1923. In fact the provisions of the Treaty governing the release of deportees were not enacted until January 1924 by which time an estimated twothirds of them had perished. ${ }^{150}$

Estimates regarding the scope of the Smyrna disaster vary wildly. Admiral Bristol, the American High Commissioner in Constantinople downplayed the "exaggerated and alarming reports" of the disaster. ${ }^{151}$ He said: "It is impossible to estimate the number of deaths due to killings, fire, and execution, but the total probably does not exceed 2,000," a number far lower than most other estimates. De Cramer stated that 1,200 were killed in Bournabat alone. Bristol's estimate was generally accepted in the West, causing one scholar to describe the fire as one "in which, after all, though the loss of property had been vast, the loss of human life had been comparatively small." ${ }^{152}$ At the other end of the scale, the American Vice-Consul at Smyrna, George Horton, numbered the deaths at 100,000, or almost a quarter of the swollen population. ${ }^{153}$ Comparisons of the population before and after the disaster show some 190,000 people unaccounted for. ${ }^{154}$ There is no exact accounting of the number of deportees taken to the interior, but Greek sources place these at $100,000 .{ }^{155}$ The types of statistical analysis engaged in by the above sources tend to be crude and unsatisfactory. It is probably wise to treat all figures, high and low, with some degree of caution. After the Treaty of Lausanne, Turkey proposed an exchange of remaining populations in a separate convention with Greece. As a result of the Treaty of Exchange, 390,000 Moslems left Greece for Turkey, while 1,250,000 Greeks and 100,000 Armenians came to Greece from Turkish territory (including Eastern Thrace which was ceded in the treaty). ${ }^{156}$ However the numbers of dead and relocated are calculated, one thing was certain - after 1924 Turkey no longer had the problem of significant populations of Christian minorities in its territory.

In addition to restoring 'Turkey's boundaries to the 1918 status, ridding Turkey of its Christian minorities was an important plank of Kemalist nationalism. The destruction of Smyrna, combined with the Treaty of Exchange, did more to accomplish this than any

150 Housepian, The Smyrna Affair, 207-09.

151 Ibid., 190

152 Kinross, Atatürk 372.

153 Housepian, The Smyrna Affair, 190,258; Horton, The Blight of Asia, 173-76.

154 Housepian, The Smyrna Affair, 258.

155 U.S. Department of State. Papers Relating to the Foreign Relations of the United States. 1922, vol. 2 (Washington: U.S. Dept. of State): 941

156 For an interesting follow up of what happened to the transplanted Ottoman Christians see Renée Hirschon, Heirs of the Greek Catastrophe (Oxford: Clarendon Press, 1989). Figures for the numbers exchanged are far more reliable than the estimates of deaths in Smyrna. 
other act. Of the fire Kemal told Latife that it is "a sign that Turkey is purged of traitors, the Christians, and of the foreigners, and that Turkey is for the Turks." 157 It is not clear whether or not Kemal himself took a Nero-like approach to the question of urban renewal and Christian minorities in Smyrna. At the time of the outbreak, he was either in Bournabat discussing negotiations with the Allies and planning the coming advance on the Dardanelles, or in Göztepe engaged in his pursuit of the fascinating Latifé. Smyrna was under the military control of the cruel and xenophobic Nureddin Pasha, who had both the desire and, as governor, the authority to rid the city of Christians by any means at his disposal. ${ }^{158}$ It seems probable that the orders to use fire in the Armenian quarter emanated from him, and not higher up. It is also possible that the conflagration did indeed get out of control and the destruction was greater than intended.

It is likely that, had these events occurred at the close of the twentieth century, special prosecutors would be preparing war crimes indictments against the Turkish commanders before international tribunals. Yet it would be wrong to judge these events from the moral high ground of the new millennium when the world has had to react to far grosser violations of human rights. In 1922 nationalism, even ethnic nationalism, was considered something of a virtue to be admired. Kemal's provisional government was waging a war of liberation against an enemy that not only occupied its territory but also had persecuted the Turkish inhabitants. Smyrna was seen as a city in which a significant proportion of the inhabitants had committed treason through cooperating or collaboration with a foreign invader. It should also be noted that even if the direst calculations of casu- alties are accepted, over $85 \%$ of the Ottoman Christians survived to be relocated. Tragic though the catastrophe was it cannot compare to many incidents later in the century. Kemal was perhaps wrong to trivialize the fire to Admiral Dumesmil as a disagreeable incident and an "episode of secondary importance." 159 Kemal's staff officers, as reported by de Cramer, gave a more acceptable response when they stated that they disapproved of the actions of their troops, but rationalized these activities because of the horrors committed against Turks that those same troops had seen for the previous two weeks in the interior.

After the conquest of Smyrna, Kemal's armies moved towards the Dardanelles and the allied positions at Chanak. As the Turkish troops arrived, the French and Italian troops pulled out leaving the British surprised and alone. There was an uneasy truce while diplomats tried to find a solution to the impasse. The eventual result was that Kemal was given Constantinople and Eastern Thrace, achieving all of his war aims, while his great opponent Lloyd George fell from power. Kemal was then free to consolidate his own power and begin the task of building a modern, secular state. France's duplicitous diplomacy availed little in the end since Kemal had seen, and never forgiven, Franchet d'Espèrey's entry into Constantinople. The economic concessions that France had sought and thought guaranteed were given to Admiral Chester's American group in April 1923.

In these greater events the fact that Smyrna was destroyed and could never be rebuilt as it had been seemed almost overlooked. As one observer put it: "Nine days before I found it a beautiful Greek city with happy homes and prosperous people. Today I

157 Armstrong, Grey Wolf: Mustafa Kemal, 203. Armstrong states (p. 10) that the quotations in his book were either "supplied by Mustafa Kemal or obtained from documentary or verbal sources that had been severely tested and carefully weighed before their veracity and value have been accepted."

158 Kinross, Atatïrk, 370.

159 Ibid., 372. 
leave it a Turkish city, dead and in ruins." 160 The modern and wholly Turkish city of Izmir was built on the ruins of Smyrna, inherited some of Smyrna's liberal and cosmopolitan outlook, and may itself be a source of pride today. Yet Smyrna was lost, its destruction foreshadowing the fate that was shortly awaiting other great multicultural cities of the twentieth century like Danzig and Beirut.

\section{ACKNOWLEDGEMENTS}

I am grateful to Professors Steven Davis (Simon Fraser University), Mary Ann Glendon (Harvard Law School), Resat Kasaba (University of Washington) and Bruce Trigger (McGill University) for reading and commenting on the manuscript. Sinan Kuneralp (Director of Isis Press, Istanbul), Leyla Neyzi (Sabanci University), Irvin Schick, Zekeriya Turkmen and Gurel Tuzun all provided helpful information over the internet. Warren Dicks (Universidad Autónoma de Barcelona) did his usual eagle-eyed proof-reading work. A number of Whittall descendants graciously granted interviews or responded to correspondence as follows: Sebastian Bell, Barbara Jackson, Paul McKernan, Mary Giraud Whittall and Ian Wookey. Sally Gallia kindly undertook the time-consuming task of transcribing relevant parts of Hortense Wood's diary, with the permission of Wood's greatniece Renée Steinbüchel. She also provided other useful information from her database of the Bornova Anglican Cemetery (now published and available for purchase). My greatest debt is to Yildiz Belger, a freelance artist in Izmir, who not only translated and transmitted to me many Turkish sources related to the history of Anatolia, but also visited local cemeteries and interviewed a variety of people to track down information on the Whittall, Wood and de Cramer families. Mrs. Belger also made the important contact with Renée Steinbüchel and Sally Gallia. 